\title{
Orchestration of angiogenesis by immune cells
}

\section{Antonino Bruno ${ }^{*}$, Arianna Pagani ${ }^{2}$, Laura Pulze ${ }^{2}$, Adriana Albini ${ }^{3}$, Katiuscia Dallaglio ${ }^{3}$, Douglas M. Noonan ${ }^{1,2}$ and Lorenzo Mortara ${ }^{2}$}

1 Scientific and Technology Pole, IRCCS MultiMedica, Milan, Italy

${ }^{2}$ Department of Biotechnology and Life Sciences, University of Insubria, Varese, Italy

${ }^{3}$ Department of Research and Statistics, IRCCS Arcispedale Santa Maria Nuova, Reggio Emilia, Italy

\section{Edited by:}

Jozsef Dudas, Medical University Innsbruck, Austria

Reviewed by:

Viktor Umansky, German Cancer Research Center, Germany

Fabian Benencia, Ohio University, USA

*Correspondence:

Antonino Bruno, IRCCS MultiMedica, Via Fantoli 16/15, Milan 20138, Italy

e-mail: antonino.bruno@

multimedica.it
It is widely accepted that the tumor microenvironment (TUMIC) plays a major role in cancer and is indispensable for tumor progression. The TUMIC involves many "players" going well beyond the malignant-transformed cells, including stromal, immune, and endothelial cells (ECS). The non-malignant cells can acquire tumor-promoting functions during carcinogenesis. In particular, these cells can "orchestrate" the "symphony" of the angiogenic switch, permitting the creation of new blood vessels that allows rapid expansion and progression toward malignancy. Considerable attention within the context of tumor angiogenesis should focus not only on the ECs, representing a fundamental unit, but also on immune cells and on the inflammatory tumor infiltrate. Immune cells infiltrating tumors typically show a tumor-induced polarization associated with attenuation of antitumor functions and generation of pro-tumor activities, among these angiogenesis. Here, we propose a scenario suggesting that the angiogenic switch is an immune switch arising from the pro-angiogenic polarization of immune cells. This view links immunity, inflammation, and angiogenesis to tumor progression. Here, we review the data in the literature and seek to identify the "conductors" of this "orchestra." We also suggest that interrupting the immune $\rightarrow$ inflammation $\rightarrow$ angiogenesis $\rightarrow$ tumor progression process can delay or prevent tumor insurgence and malignant disease.

Keywords: inflammation, angiogenesis, angiogenic switch, immune cells

\section{INTRODUCTION}

Tumors are tissues: the mass of most solid tumors contains a significant portion of untransformed host cells and matrix components in addition to transformed tumor cells. Within the "concert hall" of a tumor there is an extremely heterogenic "orchestra" where numerous factors interplay with each other at the cellular and molecular levels, to create a sort of symphony known as the tumor microenvironment (TUMIC). The TUMIC generally includes a broad array of immune and inflammatory cells as well as stromal and endothelial cells (ECs). These cell types are able to develop a dynamic, often tumor-promoting function at all stages of carcinogenesis (1).

The links between cancer and angiogenesis as well as between cancer and inflammation have been extensively documented. Angiogenesis is a crucial event for cancer survival and progression, since the vascular system delivers nutrients and oxygen to cancer cells, as well as furnishing the "roadways" through which transformed cells can invade distant organs and tissues.

In the 1800s, the observation that most tumors contain numerous inflammatory leukocytes led the pathologist Rudolph Virchow to suggest a functional relationship between chronic inflammation and cancer. However in the nineteenth century (2), tumor infiltrating immune cells were considered an attempt of the immune system to reject the tumor. Only in the last three decades the role of immune cells in promoting tumor progression has come back into light (2-6). Immune cells can act against tumors through direct and indirect mechanisms, potentially leading to tumor eradication, or resulting in immuno-editing of tumors (7). Both innate and adaptive immune cells can show strong anti-tumor activities. When altered, this functional relationship plays a crucial role in inducing and shaping tumor angiogenesis, inhibiting antitumor immune responses, and promoting a favorable microenvironment in which tumor cells can survive and replicate. Within the TUMIC immune cells can be considered an orchestra conductor of a major symphony: on one hand they can directly or indirectly destroy cancer cells, on the other hand they may promote tumor growth and dissemination $(4,5)$. This "immunologic switch" within the TUMIC that can promote or inhibit tumor formation and progression to malignancy is largely due to different polarization states of the immune cells. A classic example of polarization is that of $\mathrm{T}$ cells and macrophages. $\mathrm{T}$ helper 1 (Th1) cells are programed to exert cellular cytotoxicity; by analogy, M1 macrophages are classically activated cells producing Th1 cytokines involved in acute inflammatory responses and potential cytotoxicity. While Th2 cells are skewed toward humoral immunity, M2 polarized macrophages show a phenotype associated with Th2 cytokines, tissue reconstruction, growth promotion, and angiogenesis $(4,5,8)$. Recent evidence suggests that many immune cell subsets show diverse polarization states, particularly within the TUMIC $(4,5,8,9)$. Both local and systemic immune polarization, at least in part, explains the difficulty in translating promising immunotherapy approaches into the clinic, in spite of intensive efforts over numerous years. While the anti-tumor potential of immune cells has been extensively reviewed and will be discussed 
elsewhere in this issue, here we focus on the pro-tumor activities of immune cells, in particular on angiogenesis and selected mechanisms associated with pro-tumor polarization.

This "orchestration" of tumor angiogenesis, driven by immune cells, can be considered a common feature both for solid and hematologic malignancies. It therefore represents a valid target for anti-tumor therapies and cancer preventive strategies.

\section{MACROPHAGES}

Macrophages are immune cells recruited in response to tissue damage and inflammation, acting as "professional" phagocytic cells specialized in the clearance of pathogens and antigen presentation to the adaptive immune system. Macrophages undergo activation to various polarization states on the basis of the signals coming from the surrounding microenvironment. M1 macrophages produce significant quantities of pro-inflammatory cytokines, mediate resistance against pathogens, and can kill tumor cells. M1 macrophages are generally characterized by an interleukin (IL)$12^{\text {high }}$, IL-23 $3^{\text {high }}$, IL- $10^{\text {low }}$ phenotype, driving Th1 response; they can also produce reactive oxygen and nitrogen species (ROS and NOS) $(8,10-13)$.

M2 activation is closely related to the tumor-associated macrophage (TAM) profile (8). In vitro, M2 polarization can be obtained by treating cells with specific cytokines/immune stimulants resulting in the generation of different cellular subsets. For example, the anti-inflammatory M2a phenotype is produced by IL-4 and IL-13, the M2b phenotype is generated in response to immune complexes and toll-like receptor (TLR)/IL-1 receptor ligands; finally, the M2c phenotype is induced in the presence of IL-10. M2a polarized macrophages produce Th2 cytokines with an IL-12 ${ }^{\text {low }}$, IL-23 ${ }^{\text {low }}$, IL-1 $10^{\text {high }}$ phenotype. Overall, M2 macrophages promote tissue remodeling and angiogenesis $(8,12,13)$. TAMs show a similar molecular profile (Figure 1), influencing angiogenesis, invasion, and metastasis (8), as well as subversion of adaptive immunity (13). Both M1 and M2 macrophages are recruited into tumors from circulating blood monocytes by chemokines, but they can also migrate from adjacent tissues (8).

\section{TUMOR-ASSOCIATED MACROPHAGES}

Tumor-associated macrophages are largely derived from peripheral blood monocytes recruited into the tumor mass by growth factors and chemokines. Among these are CCL2, vascular endothelial growth factor (VEGF), and the molecules involved in the CXCL12/CXCR4 signaling axis $(8,14,15)$. TAMs are recruited into and tend to accumulate in necrotic areas where they remove the tissue debris and stimulate repair processes (16-19). In keeping with this, higher numbers of TAMs are found in tumors with extensive necrosis as compared to those with limited necrotic areas (20). In addition, hypoxia stimulates production of VEGF and CXCL12 by both tumor and normal cells, these factors are associated with M2 polarization $(8,14,15)$. Hypoxia stimulates TAMs to co-operate with tumor cells in promoting revascularization (21, 22). Key players in response to hypoxia are the hypoxia-inducible factor (HIF)- $1 \alpha$ and HIF- $2 \alpha$, the latter of which is expressed in a more tissue-restricted manner. Although they have extensive sequence and functional similarity, these two molecules show several differences and even opposing activities in some cases.
Macrophages cultured under hypoxic conditions express HIF- $1 \alpha$ and HIF- $2 \alpha$ both in vitro and in vivo $(23,24)$. However, under these conditions, they express higher levels of HIF- $1 \alpha$ as compared to HIF-2 $\alpha$, and consistent with these findings, the levels of HIF- $1 \alpha$ are higher in TAMs infiltrating breast and ovarian carcinomas (23). HIF-2 $\alpha$ is expressed in human cancers and correlates with poor prognosis (25-27). Murine myeloid specific knockouts of both HIF- $1 \alpha$ and HIF- $2 \alpha$ show distinct activities in regulating the immune response. Mice lacking myeloid HIF- $1 \alpha$ show reduced migration and invasion of macrophages, limited acute inflammation, and inhibition of bactericidal activity (28-30). Mice lacking myeloid HIF-2 $\alpha$ are resistant to endotoxemia and inflammatory lesions (31). Further, they showed resistance in a colitis associated colorectal cancer model and fewer macrophages infiltrating the tumors (31).

Tumor-associated macrophages can promote angiogenesis through numerous mechanisms (Figure 1), in particular by producing pro-angiogenic factors and inducing degradation of the extracellular matrix (ECM). Among the pro-angiogenic factors produced by TAMs are VEGF, EGF, members of the FGF family which are able to stimulate the recruitment and migration of ECs, PDGF-B, also implicated in pericyte recruitment, angiogenic CXC chemokines (CXCL8/IL-8 and CXCL12, also known as stromal derived factor-1, SDF-1), and angiogenesisassociated factors such as transforming growth factor beta (TGF $\beta$ ), tumor necrosis factor alpha $(\mathrm{TNF} \alpha)$, and thymidine phosphorylase $(8,15)$. TAM-derived cytokines can also act on angiogenesis in an indirect manner by autocrine stimulation of TAM activity.

Moreover, TAMs release different proteases, including matrix metalloproteinases (MMPs 1, 2, 3, 9, and 12), as well as plasmin and urokinase plasminogen activator, whose combined action induces degradation of the basement membrane and ECM components, destabilization of the vasculature as well as migration and proliferation of ECs $(8,15,21)$. This co-operation facilitates the migration and extravasation of tumor cells during the metastatic process (32).

Tie2-expressing macrophages (TEMs) represent a TAM subset closely associated with the vasculature $(33,34)$. These cells appear to have a distinct gene signature (35) in spite of substantial overlaps between TAMs, TEMs, myeloid-derived suppressor cells (MDSCs), monocytes, and embryonic/fetal macrophages (35, 36). TEMs are also recruited at the tumor site after treatment with vascular disrupting agents, interfering with and antagonizing their action (37). This suggests that TEMs could be key targets for anti-angiogenic therapy; deletion of TEMs inhibits angiogenesis and tumor growth $(33,34,38)$. TEMs are likely to be among the myeloid cells associated with generation of the pre-metastatic niche. The pre-metastatic niche consists in the preparation of a hospitable local microenvironment that can be easily seeded by circulating tumor cells. Diverse myeloid cells are clearly involved in generation of the pre-metastatic niche $(8,39-42)$, which appears to be a key factor in metastatic dissemination. Targeting the angiopoietin (Ang)2/Tie2 axis by blocking Ang2 resulted in inhibition of Tie2 up-regulation in TAMs (43), and inhibits vessel destabilization (44), thus influencing the pre-metastatic niche and inhibiting metastatic dissemination (45). 


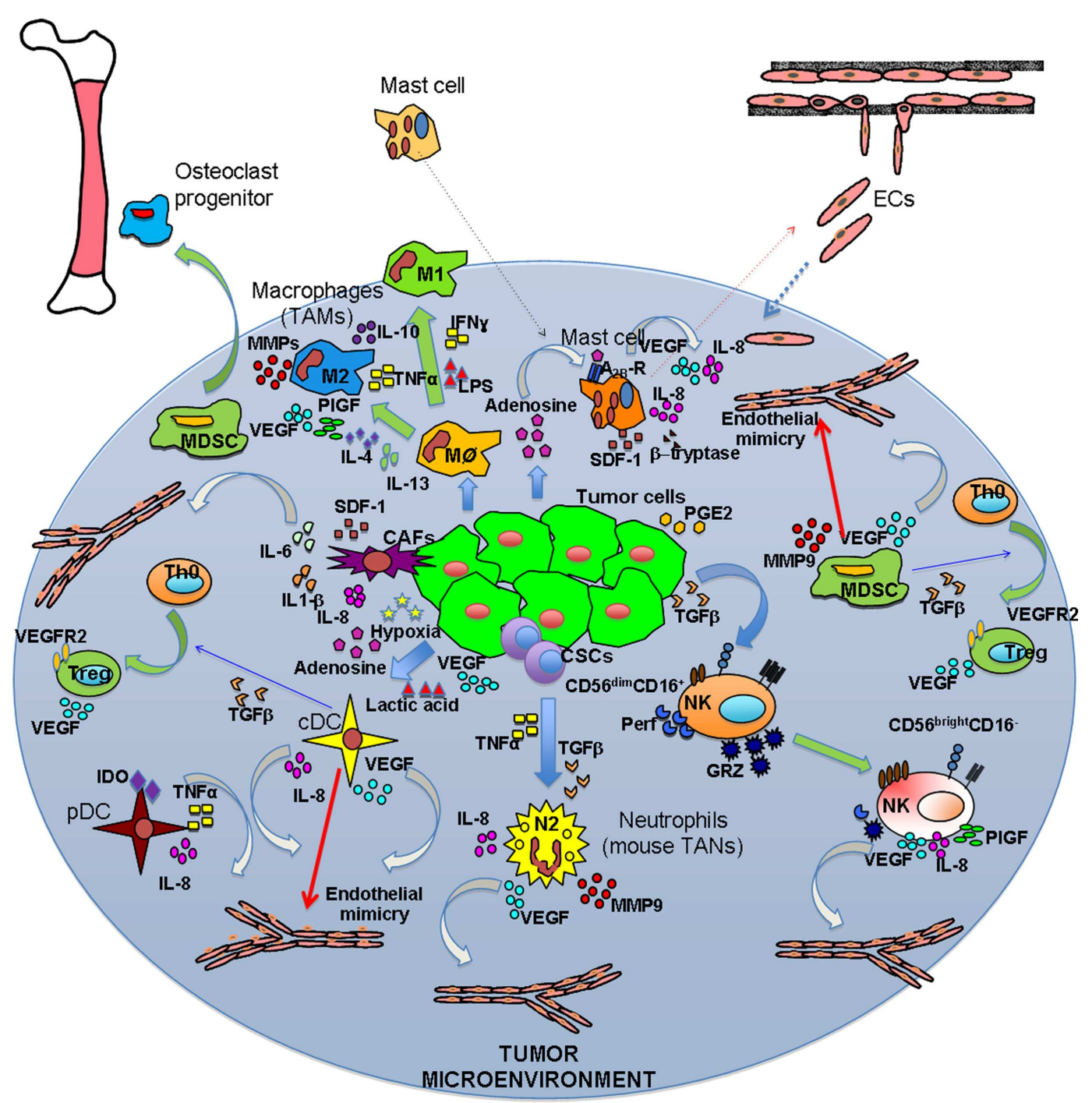

FIGURE 1 | Inflammatory orchestration of tumor angiogenesis. Both solid and hematological malignancies are associated with an inflammatory state characterized by different innate and adaptive immune cells. These cells are able to play two different symphonies at the same: on one hand they can contribute to tumor suppression and eradication, on the other they play a key role in tumor insurgence and progression. The TUMIC produces several factors, including TGF $\beta, P G E 2$, VEGF, lactic acid, and adenosine, which contribute to polarization of immune cells toward a pro-tumor/pro-angiogenic phenotype. Polarization is not only mediated by tumor cell products, but also involves crosstalk between immune cells. Ag-Ab, antigen-antibody complexes; CSCs, cancer stem cells.

\section{NEUTROPHILS}

Neutrophils are the most abundant human leukocytes and play a key role in innate immunity, representing the first immune cell recruited into sites of infection. In response to several stimuli, they are quickly recruited into areas producing "danger signals," where they employ strategies, based mainly on pattern recognition mechanisms, to contain and clear infection. Among the response mechanisms, a key player is neutrophil degranulation, leading to the release of lytic enzymes, as well as respiratory burst production of $\mathrm{ROS}\left(\mathrm{O}_{2}^{-}, \mathrm{H}_{2} \mathrm{O}_{2}, \mathrm{HOCl}\right)$ with antimicrobial potential (46). Further, neutrophils are also the source of several cytokines, including TNF $\alpha$, IL-1 $\beta$, IL-1R $\alpha$, IL-12, and VEGF and chemokines such as CXCL1, CXCL8, CXCL9, CXCL10, CCL3, and CCL4 (47) directly involved in tissue reconstruction and angiogenesis. Neutrophils have been shown to be required for vascularization of the endometrium $(48,49)$.

Neutrophils can infiltrate tumor tissues (Figure 1), having been observed in colon adenocarcinoma, myxofibrosarcoma, gastric carcinoma, and melanoma, suggesting a potential role in tumor progression and angiogenesis (50). In patients with myxofibrosarcoma, enhanced neutrophil number correlates with increased intra-tumor microvessel density (51). Interestingly, CXCL8, which is abundantly produced by tumor cells, is released in the surrounding environment, representing a potent chemoattractant for neutrophils within the tumor mass. CXCL8 and other "ELR" $\mathrm{CXC}$ chemokines have been associated with angiogenesis by direct 
activation of CXCR2 on ECs (52). However, only a subset of ECs expresses CXCR2 $(53,54)$. In vivo neutrophils are required for angiogenesis induced by CXCR2 ligands in the matrigel sponge model (55), yet are not necessary in the corneal pocket assay (52), suggesting that endothelial subtypes may be variably responsive to CXCR2 ligands, while neutrophils are uniformly responsive to these molecules. In a ras oncogene driven tumor progression model, tumor-associated neutrophils (TANs) mediate IL8 -induced angiogenesis $(56,57)$. The fact that angiostatin, an angiogenesis inhibitor identified in vivo (58), effectively targets monocytes, macrophages, and neutrophils (55, 59-64) clearly suggests that these cells play a key role in this process.

Activated neutrophils can release a variety of proteases that can degrade and remodel the ECM (Figure 1), in particular MMP9. Neutrophil-derived MMP9 has been found to be important in models of skin and rip-Tag pancreatic cancers (1) where they sustain tumor angiogenesis. $\mathrm{TNF} \alpha$, a cytokine released into the TUMIC and linked to tumor progression (65), induces neutrophil degranulation and VEGF release (66) and CXCL8, CXCL1 production (67), thus favoring angiogenesis.

Neutrophils have also been reported to produce angiostatin itself (68) and are associated with anti-angiogenic tumor repression in peroxisome proliferator-activated receptor alpha (PPAR $\alpha)$ deficient mice (69). The pro- and anti-angiogenic activities of neutrophils, and their role in tissue destruction or reconstruction, suggest that subsets of neutrophils characterized by different activities may exist $(5,70)$. Experimental evidence in murine models supports this hypothesis (71-73). When TGF $\beta$ activity was blocked, anti-tumor "N1" neutrophils were found to be associated with direct tumor cell killing as well as activation of $\mathrm{CD}^{+}$ $\mathrm{T}$ cells. In control animals, pro-tumor "N2" neutrophils were instead observed (70), indicating a role for TGF $\beta$. Depletion of neutrophils under the TGF $\beta$ blockade impaired CD8 ${ }^{+}$T cell activation and enhanced tumor growth, while in control animals TANs depletion resulted in slower growth and increased $\mathrm{CD}^{+}$activation (Figure 1). However, to date little is known concerning the existence and eventual role of neutrophil subsets in humans.

\section{DENDRITIC CELLS}

Dendritic cells (DCs) are fundamental innate immune cells with a key role in priming, orientation, and regulation of adaptive immune responses (74). DCs represent a heterogeneous population, including two major cell types: conventional (or myeloid) DCs (cDCs) and plasmacytoid DCs (pDCs) (75). They act as sentinels in the periphery, and after recognizing and capturing microbial antigens, they migrate in the secondary lymphoid organs, process foreign antigens and present peptide epitopes to naïve $\mathrm{T}$ lymphocytes, acting as potent antigen-presenting cells (APCs) (76). Both DCs subsets become fully mature following stimulation, typically in response to invading microbial pathogens, to become APCs. The cDCs mainly secrete IL-12, while pDCs release interferon $(\operatorname{IFN}) \alpha(77,78)$. However, in an immature state, they function as tolerance-inducing cells, impeding and regulating the activation of pool of latent and auto-reactive T cells and autoimmunity. Since DCs play a key role in T cell responses to antigens, several preclinical and clinical studies have been addressed to reinforce their APC function, in order to enhance anti-tumor
T immune responses (79-84). DCs represent another immune cell type that could be altered in its "conventional" function by tumor cells and the TUMIC $(75,85-89)$, thus contributing to the inflammatory "orchestration" of tumor angiogenesis.

Clinical studies have shown that in diverse tumor types, DCs display specific alterations in their stimulatory capacity, and the host can develop anomalous myeloid cell differentiation (90-96). One of the mechanisms driving this abnormal myeloid cell differentiation is the constitutive activation of signal transducers and activator of transcription-3 (STAT3) that promotes the continuous proliferation and accumulation of immature myeloid cells, including DCs, thus contributing to the suppression of tumorspecific immune responses (97). STAT3 signaling in myeloid cells has been associated with angiogenesis (98). Potential therapeutic strategies might include inhibition of STAT3 signaling (97). Soluble factors, such as VEGF, IL-6, and TGF $\beta$, can contribute to reduction of mature DC numbers, expansion and accumulation of immature tolerant DCs, and eventual polarization of DCs toward Th2 or T regulatory (Treg) induction, all features that contribute to tumor evasion from immune response. These features, described in both cancer patients and in tumor-bearing animals, have lead to the definition of a new DC cell subtype, termed regulatory DCs (regDCs) $(99,100)$. These tumor-associated DCs are potent immune-suppressive cells with different phenotypes and functions, including pDCs, cDCs, and also MDSCs, as it has very recently been described in a Lewis Lung (LL3) mouse model (101).

In human ovarian carcinomas, CXCL12-recruited pDCs have been shown to produce TNF $\alpha$ and IL-8 (Figure 1), favoring tumor angiogenesis (102). Tumor-conditioned pDCs can also act as potent immuno-suppressive cells, exerting a strong reduction of an efficient immune response (103-105). Human ovarian cancer-derived DCs co-express EC and DC markers and can therefore also significantly influence tumor angiogenesis by trans-differentiating into endothelial-like cells (Figure 1), thus promoting the formation of fully functional blood vessels (106).

In their immature state, DCs acquire the ability to trigger and guide development of Treg cells (Tregs) through TGF $\beta$ production (Figure 1), inducing a tolerogenic TUMIC (107-110). Hypoxia, which represents a key feature in the TUMIC, together with adenosine release severely inhibits DC migratory capacity $(111,112)$. In hypoxia, DCs are polarized to a Th2-stimulating phenotype (113). DCs differentiated in the presence of adenosine express higher levels of VEGF, IL-6, IL-8, IL-10, COX2, TGF $\beta$, and indoleamine 2,3-dioxygenase (IDO) (114), thus sustaining tumor angiogenesis. DCs alternatively activated with IL-10, calcitriol, and prostaglandin (PG) E2, acquire pro-angiogenic activities (115). Interestingly, many tumor-derived soluble factors, like VEGF (116), adenosine (117), PGE2 (118), and TGF $\beta$ (119), which are crucial for EC activation, migration, and functionality, are also able to mediate inhibitory effects on DC activation, resulting in $\mathrm{T}$ cell suppression and induction of Tregs. The strong alteration and inhibition in antigen presentation and DC maturation observed in cancer patients is thought to be mainly due to VEGF (120-122). Moreover, tumor-associated cDCs express high levels of the programed cell death ligand 1 (PDL1), an important negative-regulatory ligand that suppresses $\mathrm{T}$ cell activation, in response to tumor-derived VEGF (102). 
Two pro-inflammatory molecules released by DCs, TNF $\alpha$ (123, 124), and osteopontin (125-127), can also function as angiogenic factors (128-130). Other cytokines released by DCs that affect angiogenesis include IL-6 and TGF $\beta$ (129). Finally DCs can secrete pro-angiogenic chemokines such as CXCL1, CXCL2, CXCL3, CXCL5, CXCL8, and CCL2 (131-133).

On the contrary, mature cDCs can inhibit angiogenesis by releasing cytokines such as IL-12 $(64,77,102)$, and angiostatic chemokines (CXCL9, CXCL10, and CCL21) (134). Mature pDCs can produce high amounts of the anti-angiogenic cytokine IFN $\alpha$ $(78,135,136)$. Finally DCs can also produce anti-angiogenic ECM components including thrombospondin 1 (TSP) $(137,138)$ and long pentraxin-3 (PTX3) $(139,140)$ that regulate angiogenesis.

\section{MYELOID-DERIVED SUPPRESSOR CELLS}

Myeloid-derived suppressor cells represent another immune component that plays an active role in the "orchestration" of tumor promotion and immune evasion (141-143). These cells appear to be immature myeloid cells with features of both monocytes/macrophages and granulocytes. High levels of proinflammatory factors, such as GM-CSF, IL-1 $\beta$, IL-6, and S-100 within the TUMIC induce recruitment and expansion of MDSCs, and enhance their pro-tumor activity (144, 145). Moreover, MDSCs are endowed with diverse and potent immuno-suppressive machinery on innate and adaptive immune effectors. Two mainly distinct MDSC subsets have been defined in both humans and mice with some differences: granulocytic MDSCs and monocytic MDSCs [reviewed in Ref. $(141,142)]$.

Interestingly in cancer patients these cells share several features and properties with progranulocytes or immature promyelocytes (146), and their blood levels correlate with clinical cancer stage, metastatic tumor burden, and are inversely correlated with clinical outcomes (146, 147). Noteworthy, MDSCs have a direct function in promoting tumor angiogenesis through releasing soluble factors, such as MMP9 and VEGF (Figure 1), and experimental data from mouse models suggest that they are also able to differentiate into ECs $(21,148)$.

Thanks to their high plasticity these cells can acquire diverse mechanisms for suppressing anti-tumor $\mathrm{CD}^{+} \mathrm{T}$ and natural killer (NK) cells. These include inducible forms of nitric oxide synthetase (NOS2) and arginase (ARG1), and by generating ROS (149-151). Further, MDSCs possess some common features with TAMs and TANs $(5,21)$. During hypoxia in the TUMIC, infiltrating mouse MDSCs have been shown to differentiate into TAMs (152), whereas MDSCs from lungs of tumor-free mice cultured with a tumor cell conditioned medium polarized into regDCs (101), further adding a new piece in the complex puzzle of the TUMIC society.

Myeloid-derived suppressor cells down-modulate naïve $\mathrm{CD} 4^{+}$ and $\mathrm{CD}^{+} \mathrm{T}$ lymphocyte trafficking and re-circulation (153), inhibit $\mathrm{CD}^{+} \mathrm{T}$ cell tumor and tumor-draining lymph node infiltration (154), suppress NK cells $(155,156)$ and promote the conversion of naive $\mathrm{CD}^{+} \mathrm{T}$ cells into induced Tregs (157-159). It has also been shown that human monocytic MDSCs are able to produce TGF $\beta$ and retinoids thus supporting the trans-differentiation of Th17 cells into FOXP3 ${ }^{+}$-induced Tregs (160).
Recently, a novel function for MDSCs as osteoclast progenitors has been reported, suggesting a direct involvement in the osteolysis process, a common complication in breast, lung, prostate carcinomas as well as multiple myelomas (Figure 1). Osteolytic lesions are associated with a poor prognosis (161). Interestingly, an abnormal expansion of a novel subset of MDSCs in peripheral blood of pediatric patients with metastatic sarcomas with features of fibrocytes as been also characterized (162). Fibrocytes are hematopoietic stem cell-derived fibroblast precursors that are involved in chronic inflammation, fibrosis, as well as wound healing.

\section{NATURAL KILLER CELLS}

Natural killer cells are effectors lymphocytes of innate immunity that can potentially control tumors by their cytotoxic activity. Multiple human NK cells subsets have been found. The major subset is represented by $\mathrm{CD} 56^{\mathrm{dim}} \mathrm{CD} 16^{+} \mathrm{NK}$ cells that constitute about $90-95 \%$ of peripheral blood NK cells. The CD56 ${ }^{\mathrm{dim}} \mathrm{CD} 16^{+}$ NK cells readily kill target cells upon proper recognition, and only briefly secrete high cytokine levels (163). In contrast, the CD56 ${ }^{\text {bright }} \mathrm{CD} 16^{-} \mathrm{NK}$ cells (about $5-10 \%$ of peripheral blood NK cells) are poorly cytotoxic but produce large amounts of cytokines, including IFN $\gamma, \mathrm{TNF} \alpha$, and GM-CSF. Moreover, a third NK subset, decidual NK (dNK) cells, is found in the decidua (164) that are characterized by a CD56 ${ }^{\text {superbright }} \mathrm{CD} 16^{-}$phenotype. This peculiar subset is able to release significant amounts of pro-angiogenic factors, in particular VEGF, PlGF, and IL-8, necessary for spiral artery formation during decidualization $(164,165)$. The low cytolytic activity of dNK cells appears to be involved in embryonic implantation to avoid a non-self rejection process.

Similarly to several other immune cells, NK cells can also infiltrate the tumor mass where they are apparently recruited. The TUMIC is also able to affect NK functionality by a wide array or cytokines and soluble factors, either inhibiting their cytotoxic function or promoting a pro-tumor/pro-angiogenic phenotype (Figure 1). The $\mathrm{NK} \mathrm{CD56}{ }^{\text {bright }} \mathrm{CD} 16^{-}$subset predominates in non-small cell lung cancer (NSCLC), exerting very low cytotoxicity on K562 tumor cells $(166,167)$. We have recently reported that tumor infiltrating NKs in NSCLC also produce elevated levels of VEGF, PlGF, IL-8 and induce, ex vivo, EC chemotaxis, and tube formation, recapitulating the angiogenic activity of the dNK subset (9).

Transforming growth factor beta is released in the decidua and by the TUMIC, and TGF $\beta$ appears to be able to polarize the peripheral cytotoxic $\mathrm{CD} 56^{+} \mathrm{CD} 16^{+} \mathrm{NK}$ subset toward a CD56 ${ }^{\text {bright }} \mathrm{CD} 16^{-}$subset with some characteristics of $\mathrm{dNK}$ cells $(168,169)$. We observed that TGF $\beta$ induced peripheral blood NK cells to produce angiogenic factors (9), suggesting that TGF $\beta$ may be involved in "flipping" the angiogenic switch of tumor infiltrating NKs, sustaining tumor progression (Figure 1).

There is mounting evidence that NK cells are involved in regulating metastatic dissemination. NK cells are often shown to reduce metastatic efficiency of tumor lines in vivo when using the experimental metastasis assay $(170,171)$. Recent studies on the metastatic process have suggested that the tumor micro- and macro-environments may play critical roles in metastatic dissemination [reviewed in Ref. $(172,173)]$. One of the more novel concepts is that of the pre-metastatic niche, where the innate immune 
system plays a key role $(41,42,174)$. Attenuation of NK cell activity is associated with generation of the pre-metastatic niche and metastasis efficiency in murine models (40), where conditioned media from hypoxic tumor cells was associated with increased NK recruitment and reduced NK cytolytic activity. MDSCs were also enhanced within the pre-metastatic niche and may play a key role in suppressing NK activity (40). A recent study has shown that the TAM family of tyrosine kinases are involved in NK-mediated attenuation of metastasis formation and that inhibition of their activity results in NK "licensing" to kill metastatic cells in murine models of in both hematogenous and lymphatic dissemination (175), suggesting potential clinical applications.

\section{T CELLS}

The inhibition of T lymphocytes influx during angiogenesis and tissue stroma remodeling represent a peculiar feature of the TUMIC, leading to impaired T cell functionality, due to activation and expansion of tumor-polarized myeloid cells (MDSCs, M2 macrophages, TAMs, and regDCs) as well as by soluble factors released by the tumor and by the associated-inflammatory cells. The typical immuno-suppressive environment of the TUMIC (176) is characterized by a strong commitment toward induction of $\mathrm{CD}^{+}{ }^{+} \mathrm{CD} 25^{+} \mathrm{FOXP}^{+}$Treg polarization $(103,177)$, and/or Th2 and Th17 cell activation $(160,178)$. A novel mechanism by which Tregs could be directly involved in the tumor angiogenesis has recently been described (Figure 1). In ovarian cancer, hypoxiainduced angiogenesis, human, and mouse $\mathrm{CD} 4^{+} \mathrm{CD} 25^{+}$Tregs secrete higher amounts of VEGFA (as compared to CD4 ${ }^{+} \mathrm{CD} 25^{-}$ $\mathrm{T}$ cells) and promote EC proliferation in vitro and in vivo (179). Although this pro-angiogenic effect could be indirect, the depletion of Tregs in ovarian tumor-bearing-mice correlated with a strong reduction of the VEGFA at the tumor site, suggesting a relevant role of Tregs in promoting tumor angiogenesis in ovarian cancer (179).

During interaction with DCs, activated $\mathrm{CD}^{+} \mathrm{T}$ cells can acquire neuropilin 1 (NRP1), a co-receptor that binds VEGF from DCs by an intercellular transfer mechanism (180). The resulting NRP1-expressing T cells bind DC-secreted VEGFA and could potentially behave as VEGF-carrying cells, promoting angiogenesis (Figure 1). Furthermore, Tregs selectively recruited and accumulated in the TUMIC by CCL22 and CCL2 8 secretion, constitutively express NRP1 (181), indicating a potential major role of these cells among others $\mathrm{CD} 4^{+} \mathrm{T}$ cell subsets in transferring additional VEGF to the tumor site (179).

$\mathrm{T}$ regulatory cells could also directly influence and trigger alternative activation of human monocytes displaying functions and phenotypes that mirrors M2-like TAMs (182). Interestingly, the shift from Th1 to Th2 immune microenvironment has been described during transition from precancerous to invasive stage in cervical carcinoma (183) and pancreatic cancers (184).

The Th1-type cytokine IFN $\gamma$, conventionally a potent antitumor and anti-angiogenic factor (84, 185-190) has also been shown to play a role in triggering MDSC immune-suppressive function together with other cytokines, such as IL-10 (149, $191,192)$. However, the infiltration of memory cytotoxic CD8 ${ }^{+}$ T lymphocytes and Th1 cells often correlate with good clinical outcome (193), but the origin and type of tumor plays a crucial role (194-196). Efficacious anti-tumor therapeutic or vaccine approaches tested in murine models resulting in protection from tumors are characterized by strong Th1 polarization, M1 macrophage activation, a $\mathrm{TNF} \alpha$ response, and an anti-tumor IFN $\gamma$-producing $\mathrm{CD}^{+}$CTL $(187,188,190,197)$. Within the TUMIC, $\mathrm{CD}^{+}{ }^{+} \mathrm{T}$ cells are conditioned to become $\mathrm{CD}^{+}{ }^{+} \mathrm{FOXP}^{+}$ $\mathrm{T}$ regulatory cells with similar immuno-suppressive activities to that of $\mathrm{CD}^{+}$Tregs (198-200), adding more complexity to mechanisms by which the tumor polarization switch impairs immune responses. However, this newly described tumor immuno-regulatory $\mathrm{T}$ subset is a small part of the entire CD8 ${ }^{+}$ $\mathrm{T}$ cell population and little is known concerning their role in vivo and clinical relevance in cancer patients (201).

\section{B CELLS}

The role of B cells in tumor initiation, progression, and angiogenesis is still debated. However, there is clinical evidence regarding their association with good prognosis of cancer patients and potential anti-tumor effect $(202,203)$. Several studies on mouse models suggest their involvement as inhibitory cells toward $\mathrm{CD}^{+}$CTL responses (204). Experimental data support a tumorpromoting role for B cells for skin sarcoma development, showing immunoglobulin deposition within the TUMIC (205) that was dependent on TNFa (206). The pro-tumor effect of antibodyantigen complexes was shown by knock out of $\mathrm{Fc} \gamma \mathrm{R}$ receptors (207). Immune complex activation of these receptors on resident and recruited myeloid cells was also shown $(208,209)$. Interestingly, antigen-antibody complexes are involved in differentiation of M2c macrophages (8). Thus antigen-antibody complexes could influence the polarization of macrophages (Figure 1), as well as other immune cell types expressing Fc receptors (granulocytes, NK cells, DCs, MDSCs). It is not known if M2c macrophages have pro-angiogenic or even pro-tumor effects. However, these data also suggest that experiments performed using blocking antibodies must be interpreted with caution, even if proper isotype controls are used, since antigen-antibody complexes may influence many innate and even adaptive immune responses, including angiogenesis. B cell-derived lymphotoxin and activation of the NF- $\mathrm{B}$ and STAT3 pathways has also been reported to promote prostate cancer progression (210).

Recently, a regulatory B cell subset (Bregs) has been characterized with pro-tumor function that shows inhibitory activities toward adaptive immune responses (208). However, the role of adaptive $\mathrm{B}$ cells in the tumor progression and angiogenesis is still not well understood and recently published controversial information highlights the need for further investigation (208, 209).

\section{MAST CELLS}

Mast cells represent a peculiar subtype of granulocytes found in peripheral tissue, which play a central role in inflammatory and immediate allergic reactions. Mast cells were initially suggested to be involved in vascularization during rheumatoid arthritis (211214). They have also been found to be intimately involved in vascularization of hematological malignancies (215), where they are able to integrate into the vessel wall (Figure 1) by the process of vascular mimicry (216). 
Mast cell contribution to the angiogenic switch in tumors is associated with the production of diverse angiogenesis-associated cytokines and chemokines (21). Proteases produced by mast cells promote pre-malignant angiogenesis (217-219) and are becoming a target for anti-angiogenic therapies (220, 221). Moreover, $\beta$-tryptase, a neutral serine protease that represents the most abundant mediator stored in mast cell granules, plays a crucial role in inflammation (Figure 1). $\beta$-tryptase release activates the protease-activated receptor type 2 that is directly involved in vascular relaxation and contraction (222). The pro-angiogenic activity of mast cells is enhanced by the interaction of their $A_{2 B}$ receptors with adenosine (223), released during tumor growth, tissue injury, ischemia, and inflammation. The interaction between adenosine and its $A_{2 B}$ receptor leads to secretion of VEGF, IL-8, and possibly other pro-angiogenic factors (Figure 1). The effect of these factors on new capillary formation is facilitated by the concomitant stimulation of mast cell $\mathrm{A}_{3}$ receptors that induce the expression of Ang2. These, and potentially others, factors released by mast cells act synergistically, and in a paracrine fashion, on ECs to induce angiogenesis.

\section{CANCER-ASSOCIATED FIBROBLASTS}

Fibroblasts are the most abundant cell type in connective tissues, forming the structural framework of tissues through their secretion of ECM components (224). Activated fibroblasts are directly involved in wound healing and fibrosis, both processes sharing a requirement for tissue remodeling. Since tumors are wounds that "do not heal" (225), the fibroblasts within the tumor mass, classified as cancer-associated fibroblasts (CAFs) contribute to the inflammatory orchestration of tumor angiogenesis (Figure 1). Interestingly, CAFs are of multiple origins: they can originate from resident fibroblasts, mesenchymal stem cells, or mutated fibroblasts (226). In this context, CAFs are able to produce cytokines and chemokines favoring immune cell infiltration, which in turn promotes angiogenesis and metastasis.

Stromal derived factor- 1 producing pancreatic CAFs showed a synergy with IL-8 in the promotion of a complete angiogenic response (Figure 1) in recruiting ECs (227). Further, SDF-1 secreted by breast cancer CAFs has been involved in mobilization of endothelial precursor cells from bone marrow, favoring de novo angiogenesis, as well as in tumor growth through a paracrine effect on CXCR4-expressing cancer cells (228). CAFs are also able to produce CXCL14 in prostate cancer, this in turn enhances interactions with tumor cells and favor macrophages infiltration and M2 polarization (222). Recent studies reported that CAFs associated to incipient neoplasia are able to exhibit a pro-inflammatory signature, characterized by an over-expression of SDF-1, IL- 6 , and IL- $1 \beta$ that contribute to the recruitment of pro-angiogenic macrophages sustaining tumor growth (222).

\section{CONCLUDING REMARIS}

Taken together, this view suggests that the host cells that constitute the TUMIC can be polarized to a pro-tumor phenotype characterized by a pro-angiogenic activity. Since the presence of these cells is critical for successful tumor growth to clinical relevance, they are therefore very interesting clinical targets. Clinical approaches in line with these findings, yet targeting only the VEGF pathway, have been recently approved, however, as shown here, there are many cell types and mediators to target. As our basic understanding of the mechanisms of host cell polarization is increasing and the effects of these phenomena become evident and appear to be key factors in tumor biology, it is necessary to find ways to prevent or revert these events, keeping tumors in a dormant, clinically indolent state.

\section{ACKNOWLEDGMENTS}

These studies were supported by the Ministero dell'Istruzione dell'Università e della Ricerca PRIN (Programmi di Ricerca Scientifica di Rilevante Interesse Nazionale) (2010NECHBX_003 to DMN), the AIRC (Associazione Italiana per la Ricerca sul Cancro) (IG10228 to AA), and the University of Insubria FAR 2012 and FAR 2013 (to LM). Antonino Bruno is a FIRC (Fondazione Italiana per la Ricerca sul Cancro) fellow. Laura Pulze is a participant in the Cellular and Molecular Biology Doctoral program of the University of Insubria.

\section{REFERENCES}

1. Hanahan D, Coussens LM. Accessories to the crime: functions of cells recruited to the tumor microenvironment. Cancer Cell (2012) 21(3):309-22. doi:10.1016/j.ccr.2012.02.022

2. Balkwill F, Mantovani A. Inflammation and cancer: back to Virchow? Lancet (2001) 357(9255):539-45. doi:10.1016/S0140-6736(00)04046-0

3. Balkwill F, Charles KA, Mantovani A. Smoldering and polarized inflammation in the initiation and promotion of malignant disease. Cancer Cell (2005) 7(3):211-7. doi:10.1016/j.ccr.2005.02.013

4. de Visser KE, Eichten A, Coussens LM. Paradoxical roles of the immune system during cancer development. Nat Rev Cancer (2006) 6(1):24-37. doi:10.1038/ nrc1782

5. Noonan DM, De Lerma Barbaro A, Vannini N, Mortara L, Albini A. Inflammation, inflammatory cells and angiogenesis: decisions and indecisions. Cancer Metastasis Rev (2008) 27(1):31-40. doi:10.1007/s10555-007-9108-5

6. Ruffell B, DeNardo DG, Affara NI, Coussens LM. Lymphocytes in cancer development: polarization towards pro-tumor immunity. Cytokine Growth Factor Rev (2010) 21(1):3-10. doi:10.1016/j.cytogfr.2009.11.002

7. Schreiber RD, Old LJ, Smyth MJ. Cancer immunoediting: integrating immunity's roles in cancer suppression and promotion. Science (2011) 331(6024):1565-70. doi:10.1126/science.1203486

8. Mantovani A, Sica A. Macrophages, innate immunity and cancer: balance, tolerance, and diversity. Curr Opin Immunol (2010) 22(2):231-7. doi:10.1016/j. coi.2010.01.009

9. Bruno A, Focaccetti C, Pagani A, Imperatori AS, Spagnoletti M, Rotolo N, et al. The proangiogenic phenotype of natural killer cells in patients with non-small cell lung cancer. Neoplasia (2013) 15(2):133-42. doi:10.1593/neo.121758

10. Goerdt S, Orfanos CE. Other functions, other genes: alternative activation of antigen-presenting cells. Immunity (1999) 10(2):137-42. doi:10.1016/S10747613(00)80014-X

11. Goerdt S, Politz O, Schledzewski K, Birk R, Gratchev A, Guillot P, et al. Alternative versus classical activation of macrophages. Pathobiology (1999) 67(5-6):222-6. doi:10.1159/000028096

12. Gordon S. Alternative activation of macrophages. Nat Rev Immunol (2003) 3(1):23-35. doi:10.1038/nri978

13. Sica A, Bronte V. Altered macrophage differentiation and immune dysfunction in tumor development. J Clin Invest (2007) 117(5):1155-66. doi:10.1172/ JCI31422

14. Crowther M, Brown NJ, Bishop ET, Lewis CE. Microenvironmental influence on macrophage regulation of angiogenesis in wounds and malignant tumors. J Leukoc Biol (2001) 70(4):478-90. doi:10.1189/jlb.1938-3673

15. Sica A, Schioppa T, Mantovani A, Allavena P. Tumour-associated macrophages are a distinct M2 polarised population promoting tumour progression: potential targets of anti-cancer therapy. Eur J Cancer (2006) 42(6):717-27. doi:10.1016/j.ejca.2006.01.003 
16. Leek RD, Hunt NC, Landers RJ, Lewis CE, Royds JA, Harris AL. Macrophage infiltration is associated with VEGF and EGFR expression in breast cancer. J Pathol (2000) 190(4):430-6. doi:10.1002/(SICI)1096-9896(200003)190: 4<430::AID-PATH538>3.3.CO;2-Y

17. Leek RD, Landers RJ, Harris AL, Lewis CE. Necrosis correlates with high vascular density and focal macrophage infiltration in invasive carcinoma of the breast. Br J Cancer (1999) 79(5-6):991-5. doi:10.1038/sj.bjc.6690158

18. Leek RD, Lewis CE, Whitehouse R, Greenall M, Clarke J, Harris AL. Association of macrophage infiltration with angiogenesis and prognosis in invasive breast carcinoma. Cancer Res (1996) 56(20):4625-9.

19. O'Sullivan C, Lewis CE. Tumour-associated leucocytes: friends or foes in breast carcinoma. J Pathol (1994) 172(3):229-35. doi:10.1002/path.1711720302

20. Harmey JH, Dimitriadis E, Kay E, Redmond HP, Bouchier-Hayes D. Regulation of macrophage production of vascular endothelial growth factor (VEGF) by hypoxia and transforming growth factor beta-1. Ann Surg Oncol (1998) 5(3):271-8. doi:10.1007/BF02303785

21. Murdoch C, Muthana M, Coffelt SB, Lewis CE. The role of myeloid cells in the promotion of tumour angiogenesis. Nat Rev Cancer (2008) 8(8):618-31. doi:10.1038/nrc2444

22. Schioppa T, Uranchimeg B, Saccani A, Biswas SK, Doni A, Rapisarda A, et al. Regulation of the chemokine receptor CXCR4 by hypoxia. J Exp Med (2003) 198(9):1391-402. doi:10.1084/jem.20030267

23. Burke B, Tang N, Corke KP, Tazzyman D, Ameri K, Wells M, et al. Expression of HIF-lalpha by human macrophages: implications for the use of macrophages in hypoxia-regulated cancer gene therapy. J Pathol (2002) 196(2):204-12. doi:10.1002/path.1029

24. Griffiths L, Binley K, Iqball S, Kan O, Maxwell P, Ratcliffe P, et al. The macrophage - a novel system to deliver gene therapy to pathological hypoxia. Gene Ther (2000) 7(3):255-62. doi:10.1038/sj.gt.3301058

25. Kawanaka T, Kubo A, Ikushima H, Sano T, Takegawa Y, Nishitani H. Prognostic significance of HIF-2alpha expression on tumor infiltrating macrophages in patients with uterine cervical cancer undergoing radiotherapy. J Med Invest (2008) 55(1-2):78-86. doi:10.2152/jmi.55.78

26. Leek RD, Talks KL, Pezzella F, Turley H, Campo L, Brown NS, et al. Relation of hypoxia-inducible factor-2 alpha (HIF-2 alpha) expression in tumorinfiltrative macrophages to tumor angiogenesis and the oxidative thymidine phosphorylase pathway in human breast cancer. Cancer Res (2002) 62(5):1326-9.

27. Talks KL, Turley H, Gatter KC, Maxwell PH, Pugh CW, Ratcliffe PJ, et al. The expression and distribution of the hypoxia-inducible factors HIF-1alpha and HIF-2alpha in normal human tissues, cancers, and tumor-associated macrophages. Am J Pathol (2000) 157(2):411-21. doi:10.1016/S0002-9440(10) 64554-3

28. Cramer T, Yamanishi Y, Clausen BE, Forster I, Pawlinski R, Mackman N, et al. HIF-lalpha is essential for myeloid cell-mediated inflammation. Cell (2003) 112(5):645-57. doi:10.1016/S0092-8674(03)00154-5

29. Peyssonnaux C, Datta V, Cramer T, Doedens A, Theodorakis EA, Gallo RL, et al. HIF-1alpha expression regulates the bactericidal capacity of phagocytes. J Clin Invest (2005) 115(7):1806-15. doi:10.1172/JCI23865

30. Peyssonnaux C, Cejudo-Martin P, Doedens A, Zinkernagel AS, Johnson RS, Nizet V. Cutting edge: essential role of hypoxia inducible factor-1alpha in development of lipopolysaccharide-induced sepsis. J Immunol (2007) 178(12):7516-9. doi:10.4049/jimmunol.178.12.7516

31. Imtiyaz HZ, Williams EP, Hickey MM, Patel SA, Durham AC, Yuan LJ, et al. Hypoxia-inducible factor 2alpha regulates macrophage function in mouse models of acute and tumor inflammation. J Clin Invest (2010) 120(8):2699-714. doi:10.1172/JCI39506

32. Xia D, Wang F, Parmely MJ. Inhibition of nuclear factor-kappab activation in mouse macrophages and the RAW 264.7 cell line by a synthetic adenyl carbocyclic nucleoside. Biochem Pharmacol (2000) 60(5):717-27. doi:10.1016/ S0006-2952(00)00367-1

33. De Palma M, Murdoch C, Venneri MA, Naldini L, Lewis CE. Tie2-expressing monocytes: regulation of tumor angiogenesis and therapeutic implications. Trends Immunol (2007) 28(12):519-24. doi:10.1016/j.it.2007.09.004

34. De Palma M, Naldini L. Tie2-expressing monocytes (TEMs): novel targets and vehicles of anticancer therapy? Biochim Biophys Acta (2009) 1796(1):5-10. doi:10.1016/j.bbcan.2009.04.001
35. Pucci F, Venneri MA, Biziato D, Nonis A, Moi D, Sica A, et al. A distinguishing gene signature shared by tumor-infiltrating Tie2-expressing monocytes, blood "resident" monocytes, and embryonic macrophages suggests common functions and developmental relationships. Blood (2009) 114(4):901-14. doi:10.1182/blood-2009-01-200931

36. Coffelt SB, Lewis CE, Naldini L, Brown JM, Ferrara N, De Palma M. Elusive identities and overlapping phenotypes of proangiogenic myeloid cells in tumors. Am J Pathol (2010) 176(4):1564-76. doi:10.2353/ajpath.2010.090786

37. Welford AF, Biziato D, Coffelt SB, Nucera S, Fisher M, Pucci F, et al TIE2-expressing macrophages limit the therapeutic efficacy of the vasculardisrupting agent combretastatin A4 phosphate in mice. J Clin Invest (2011) 121(5):1969-73. doi:10.1172/JCI44562

38. Pulaski HL, Spahlinger G, Silva IA, McLean K, Kueck AS, Reynolds RK, et al. Identifying alemtuzumab as an anti-myeloid cell antiangiogenic therapy for the treatment of ovarian cancer. J Transl Med (2009) 7:49. doi:10.1186/14795876-7-49

39. Albini A, Cesana E, Noonan DM. Cancer stem cells and the tumor microenvironment: soloists or choral singers. Curr Pharm Biotechnol (2011) 12(2):171-81. doi:10.2174/138920111794295756

40. Sceneay J, Chow MT, Chen A, Halse HM, Wong CS, Andrews DM, et al. Primary tumor hypoxia recruits CD11b+/Ly6Cmed/Ly6G+ immune suppressor cells and compromises NK cell cytotoxicity in the premetastatic niche. Cancer Res (2012) 72(16):3906-11. doi:10.1158/0008-5472.CAN-11-3873

41. Kaplan RN, Rafii S, Lyden D. Preparing the "soil": the premetastatic niche. Cancer Res (2006) 66(23):11089-93. doi:10.1158/0008-5472.CAN-06-2407

42. Psaila B, Lyden D. The metastatic niche: adapting the foreign soil. Nat Rev Cancer (2009) 9(4):285-93. doi:10.1038/nrc2621

43. Mazzieri R, Pucci F, Moi D, Zonari E, Ranghetti A, Berti A, et al. Targeting the ANG2/TIE2 axis inhibits tumor growth and metastasis by impairing angiogenesis and disabling rebounds of proangiogenic myeloid cells. Cancer Cell (2011) 19(4):512-26. doi:10.1016/j.ccr.2011.02.005

44. Holopainen T, Saharinen P, D’Amico G, Lampinen A, Eklund L, Sormunen $\mathrm{R}$, et al. Effects of angiopoietin-2 blocking antibody on endothelial cell-cell junctions and lung metastasis. J Natl Cancer Inst (2012) 104(6):461-75. doi:10.1093/jnci/djs009

45. Albini A, Noonan DM. Angiopoietin2 and Tie2: tied to lymphangiogenesis and lung metastasis. New perspectives in antimetastatic antiangiogenic therapy. J Natl Cancer Inst (2012) 104(6):429-31. doi:10.1093/jnci/djs032

46. Borregaard N, Cowland JB. Granules of the human neutrophilic polymorphonuclear leukocyte. Blood (1997) 89(10):3503-21.

47. Scapini P, Lapinet-Vera JA, Gasperini S, Calzetti F, Bazzoni F, Cassatella MA. The neutrophil as a cellular source of chemokines. Immunol Rev (2000) 177:195-203. doi:10.1034/j.1600-065X.2000.17706.x

48. Gargett CE, Lederman F, Heryanto B, Gambino LS, Rogers PA. Focal vascular endothelial growth factor correlates with angiogenesis in human endometrium. Role of intravascular neutrophils. Hum Reprod (2001) 16(6):1065-75. doi:10. 1093/humrep/16.6.1065

49. Heryanto B, Girling JE, Rogers PA. Intravascular neutrophils partially mediate the endometrial endothelial cell proliferative response to oestrogen in ovariectomised mice. Reproduction (2004) 127(5):613-20. doi:10.1530/rep.1.00161

50. Tazzyman S, Lewis CE, Murdoch C. Neutrophils: key mediators of tumour angiogenesis. Int J Exp Pathol (2009) 90(3):222-31. doi:10.1111/j.1365-2613. 2009.00641.x

51. Mentzel T, Brown LF, Dvorak HF, Kuhnen C, Stiller KJ, Katenkamp D, et al. The association between tumour progression and vascularity in myxofibrosarcoma and myxoid/round cell liposarcoma. Virchows Arch (2001) 438(1):13-22. doi:10.1007/s004280000327

52. Strieter RM, Burdick MD, Gomperts BN, Belperio JA, Keane MP. CXC chemokines in angiogenesis. Cytokine Growth Factor Rev (2005) 16(6):593-609. doi:10.1016/j.cytogfr.2005.04.007

53. Benelli R, Albini A, Noonan D. Neutrophils and angiogenesis: potential initiators of the angiogenic cascade. In: Cassatella M, editor. The Neutrophil: An Emerging Regulator of Inflammatory and Immune Response (Vol. 83), Basel: Karger (2003). p. 167-81.

54. Benelli R, Lorusso G, Albini A, Noonan DM. Cytokines and chemokines as regulators of angiogenesis in health and disease. Curr Pharm Des (2006) 12(24):3101-15. doi:10.2174/138161206777947461 
55. Benelli R, Morini M, Carrozzino F, Ferrari N, Minghelli S, Santi L, et al. Neutrophils as a key cellular target for angiostatin: implications for regulation of angiogenesis and inflammation. FASEB J (2002) 16(2):267-9. doi:10.1096/fj.01-0651fje

56. Sparmann A, Bar-Sagi D. Ras-induced interleukin-8 expression plays a critical role in tumor growth and angiogenesis. Cancer Cell (2004) 6(5):447-58. doi:10.1016/j.ccr.2004.09.028

57. Karin M. Inflammation and cancer: the long reach of Ras. Nat Med (2005) 11(1):20-1. doi:10.1038/nm0105-20

58. O’Reilly MS, Holmgren L, Shing Y, Chen C, Rosenthal RA, Moses M, et al. Angiostatin: a novel angiogenesis inhibitor that mediates the suppression of metastases by a Lewis lung carcinoma. Cell (1994) 79(2):315-28. doi:10.1016/ 0092-8674(94)90200-3

59. Benelli R, Barbero A, Ferrini S, Scapini P, Cassatella M, Bussolino F, et al. Human immunodeficiency virus transactivator protein (Tat) stimulates chemotaxis, calcium mobilization, and activation of human polymorphonuclear leukocytes: implications for Tat-mediated pathogenesis. J Infect Dis (2000) 182(6):1643-51. doi:10.1086/317597

60. Benelli R, Morini M, Brigati C, Noonan DM, Albini A. Angiostatin inhibits extracellular HIV-Tat-induced inflammatory angiogenesis. Int J Oncol (2003) 22(1):87-91. doi:10.3892/ijo.22.1.87

61. Chavakis T, Athanasopoulos A, Rhee JS, Orlova V, Schmidt-Woll T, Bierhaus A, et al. Angiostatin is a novel anti-inflammatory factor by inhibiting leukocyte recruitment. Blood (2005) 105(3):1036-43. doi:10.1182/blood-2004-01-0166

62. Perri SR, Annabi B, Galipeau J. Angiostatin inhibits monocyte/macrophage migration via disruption of actin cytoskeleton. FASEB J (2007) 21(14):3928-36. doi:10.1096/fj.07-8158com

63. Perri SR, Nalbantoglu J, Annabi B, Koty Z, Lejeune L, Francois M, et al. Plasminogen kringle 5-engineered glioma cells block migration of tumorassociated macrophages and suppress tumor vascularization and progression. Cancer Res (2005) 65(18):8359-65. doi:10.1158/0008-5472.CAN-05-0508

64. Albini A, Brigati C, Ventura A, Lorusso G, Pinter M, Morini M, et al. Angiostatin anti-angiogenesis requires $\mathrm{IL}-12$ : the innate immune system as a key target. J Transl Med (2009) 7:5. doi:10.1186/1479-5876-7-5

65. Balkwill F. TNF-alpha in promotion and progression of cancer. Cancer Metastasis Rev (2006) 25(3):409-16. doi:10.1007/s10555-006-9005-3

66. McCourt M, Wang JH, Sookhai S, Redmond HP. Proinflammatory mediators stimulate neutrophil-directed angiogenesis. Arch Surg (1999) 134(12):1325-31. doi:10.1001/archsurg.134.12.1325

67. Cassatella MA. Neutrophil-derived proteins: selling cytokines by the pound. Adv Immunol (1999) 73:369-509. doi:10.1016/S0065-2776(08)60791-9

68. Scapini P, Nesi L, Morini M, Tanghetti E, Belleri M, Noonan D, et al. Generation of biologically active angiostatin kringle 1-3 by activated human neutrophils. J Immunol (2002) 168(11):5798-804. doi:10.4049/jimmunol.168.11.5798

69. Kaipainen A, Kieran MW, Huang S, Butterfield C, Bielenberg D, Mostoslavsky $\mathrm{G}$, et al. PPARalpha deficiency in inflammatory cells suppresses tumor growth. PLoS One (2007) 2:e260. doi:10.1371/journal.pone.0000260

70. Fridlender ZG, Albelda SM. Tumor-associated neutrophils: friend or foe? Carcinogenesis (2012) 33(5):949-55. doi:10.1093/carcin/bgs123

71. Tsuda Y, Takahashi H, Kobayashi M, Hanafusa T, Herndon DN, Suzuki F. Three different neutrophil subsets exhibited in mice with different susceptibilities to infection by methicillin-resistant Staphylococcus aureus. Immunity (2004) 21(2):215-26. doi:10.1016/j.immuni.2004.07.006

72. Nozawa H, Chiu C, Hanahan D. Infiltrating neutrophils mediate the initial angiogenic switch in a mouse model of multistage carcinogenesis. Proc Natl Acad Sci U S A (2006) 103(33):12493-8. doi:10.1073/pnas.0601807103

73. Fridlender ZG, Sun J, Kim S, Kapoor V, Cheng G, Ling L, et al. Polarization of tumor-associated neutrophil phenotype by TGF-beta: "N1" versus "N2" TAN. Cancer Cell (2009) 16(3):183-94. doi:10.1016/j.ccr.2009.06.017

74. Mellman I, Steinman RM. Dendritic cells: specialized and regulated antigen processing machines. Cell (2001) 106(3):255-8. doi:10.1016/S0092-8674(01) 00449-4

75. Liu K, Nussenzweig MC. Origin and development of dendritic cells. Immunol Rev (2010) 234(1):45-54. doi:10.1111/j.0105-2896.2009.00879.x

76. Steinman RM, Banchereau J. Taking dendritic cells into medicine. Nature (2007) 449(7161):419-26. doi:10.1038/nature06175

77. Trinchieri G. Interleukin-12 and the regulation of innate resistance and adaptive immunity. Nat Rev Immunol (2003) 3(2):133-46. doi:10.1038/nri1001
78. Asselin-Paturel C, Trinchieri G. Production of type I interferons: plasmacytoid dendritic cells and beyond. J Exp Med (2005) 202(4):461-5. doi:10.1084/jem. 20051395

79. Condon C, Watkins SC, Celluzzi CM, Thompson K, Falo LD Jr. DNA-based immunization by in vivo transfection of dendritic cells. Nat Med (1996) 2(10):1122-8. doi:10.1038/nm1096-1122

80. Porgador A, Staats HF, Itoh Y, Kelsall BL. Intranasal immunization with cytotoxic T-lymphocyte epitope peptide and mucosal adjuvant cholera toxin: selective augmentation of peptide-presenting dendritic cells in nasal mucosaassociated lymphoid tissue. Infect Immun (1998) 66(12):5876-81.

81. Ferlazzo G, Semino C, Meta M, Procopio F, Morandi B, Melioli G. T lymphocytes express B7 family molecules following interaction with dendritic cells and acquire bystander costimulatory properties. Eur J Immunol (2002) 32(11):3092-101. doi:10.1002/1521-4141(200211)32:11<3092::AIDIMMU3092>3.0.CO;2-0

82. Blattman JN, Wherry EJ, Ha SJ, van der Most RG, Ahmed R. Impact of epitope escape on PD-1 expression and CD8 T-cell exhaustion during chronic infection. J Virol (2009) 83(9):4386-94. doi:10.1128/JVI.02524-08

83. Narayanan P, Lapteva N, Seethammagari M, Levitt JM, Slawin KM, Spencer DM. A composite MyD88/CD40 switch synergistically activates mouse and human dendritic cells for enhanced antitumor efficacy. J Clin Invest (2011) 121(4):1524-34. doi:10.1172/JCI44327

84. Morandi B, Mortara L, Chiossone L, Accolla RS, Mingari MC, Moretta L, et al. Dendritic cell editing by activated natural killer cells results in a more protective cancer-specific immune response. PLoS One (2012) 7(6):e39170. doi:10.1371/journal.pone.0039170

85. Almand B, Resser JR, Lindman B, Nadaf S, Clark JI, Kwon ED, et al. Clinical significance of defective dendritic cell differentiation in cancer. Clin Cancer Res (2000) 6(5):1755-66.

86. Gottfried E, Kunz-Schughart LA, Ebner S, Mueller-Klieser W, Hoves S, Andreesen R, et al. Tumor-derived lactic acid modulates dendritic cell activation and antigen expression. Blood (2006) 107(5):2013-21. doi:10.1182/blood2005-05- 1795

87. Sozzani S, Rusnati M, Riboldi E, Mitola S, Presta M. Dendritic cell-endothelial cell cross-talk in angiogenesis. Trends Immunol (2007) 28(9):385-92. doi:10. 1016/j.it.2007.07.006

88. Fricke I, Gabrilovich DI. Dendritic cells and tumor microenvironment: a dangerous liaison. Immunol Invest (2006) 35(3-4):459-83. doi:10.1080/ 08820130600803429

89. Herber DL, Cao W, Nefedova Y, Novitskiy SV, Nagaraj S, Tyurin VA, et al. Lipid accumulation and dendritic cell dysfunction in cancer. Nat Med (2010) 16(8):880-6. doi:10.1038/nm.2172

90. Gabrilovich D. Mechanisms and functional significance of tumour-induced dendritic-cell defects. Nat Rev Immunol (2004) 4(12):941-52. doi:10.1038/ nri1498

91. Pinzon-Charry A, Ho CS, Maxwell T, McGuckin MA, Schmidt C, Furnival C, et al. Numerical and functional defects of blood dendritic cells in early- and late-stage breast cancer. Br J Cancer (2007) 97(9):1251-9. doi:10.1038/sj.bjc. 6604018

92. Perrot I, Blanchard D, Freymond N, Isaac S, Guibert B, Pacheco Y, et al. Dendritic cells infiltrating human non-small cell lung cancer are blocked at immature stage. J Immunol (2007) 178(5):2763-9. doi:10.4049/jimmunol.178.5.2763

93. Bellone G, Carbone A, Smirne C, Scirelli T, Buffolino A, Novarino A, et al. Cooperative induction of a tolerogenic dendritic cell phenotype by cytokines secreted by pancreatic carcinoma cells. J Immunol (2006) 177(5):3448-60. doi:10.4049/jimmunol.177.5.3448

94. Lee BN, Follen M, Rodriquez G, Shen DY, Malpica A, Shearer WT, et al. Deficiencies in myeloid antigen-presenting cells in women with cervical squamous intraepithelial lesions. Cancer (2006) 107(5):999-1007. doi:10.1002/ cncr.22092

95. Ormandy LA, Farber A, Cantz T, Petrykowska S, Wedemeyer H, Horning M, et al. Direct ex vivo analysis of dendritic cells in patients with hepatocellular carcinoma. World J Gastroenterol (2006) 12(20):3275-82. doi:10.3748/wjg.v12. i20.3275

96. Krempski J, Karyampudi L, Behrens MD, Erskine CL, Hartmann L, Dong H, et al. Tumor-infiltrating programmed death receptor-1+ dendritic cells mediate immune suppression in ovarian cancer. Jimmunol (2011) 186(12):6905-13. doi:10.4049/jimmunol.1100274 
97. Yu H, Pardoll D, Jove R. STATs in cancer inflammation and immunity: a leading role for STAT3. Nat Rev Cancer (2009) 9(11):798-809. doi:10.1038/nrc2734

98. Kujawski M, Kortylewski M, Lee H, Herrmann A, Kay H, Yu H. Stat3 mediates myeloid cell-dependent tumor angiogenesis in mice. J Clin Invest (2008) 118(10):3367-77. doi:10.1172/JCI35213

99. Ma Y, Shurin GV, Gutkinb DW, Shurin MR. Tumor associated regulatory dendritic cells. Semin Cancer Biol (2012) 22:298-306. doi:10.1016/j.semcancer. 2012.02.010

100. Shurin GV, Ma Y, Shurin MR. Immunosuppressive mechanisms of regulatory dendritic cells in cancer. Cancer Microenviron (2013) 6:159-67. doi:10.1007/ s12307-013-0133-3

101. Zhong H, Gutkin DW, Han B, Ma Y, Keskinov AA, Shurin MR, et al. Origin and pharmacological modulation of tumor-associated regulatory dendritic cells. Int J Cancer (2014) 134:2633-45. doi:10.1002/ijc.28590

102. Curiel TJ, Cheng P, Mottram P, Alvarez X, Moons L, Evdemon-Hogan M, et al. Dendritic cell subsets differentially regulate angiogenesis in human ovarian cancer. Cancer Res (2004) 64(16):5535-8. doi:10.1158/0008-5472.CAN-041272

103. Zou L, Barnett B, Safah H, Larussa VF, Evdemon-Hogan M, Mottram P, et al. Bone marrow is a reservoir for $\mathrm{CD} 4+\mathrm{CD} 25+$ regulatory $\mathrm{T}$ cells that traffic through CXCL12/CXCR4 signals. Cancer Res (2004) 64(22):8451-5. doi:10.1158/0008-5472.CAN-04- 1987

104. Kryczek I, Lange A, Mottram P, Alvarez X, Cheng P, Hogan M, et al. CXCL12 and vascular endothelial growth factor synergistically induce neoangiogenesis in human ovarian cancers. Cancer Res (2005) 65(2):465-72.

105. Rabinovich GA, Gabrilovich D, Sotomayor EM. Immunosuppressive strategies that are mediated by tumor cells. Annu Rev Immunol (2007) 25:267-96. doi:10.1146/annurev.immunol.25.022106.141609

106. Coukos G, Benencia F, Buckanovich RJ, Conejo-Garcia JR. The role of dendritic cell precursors in tumour vasculogenesis. Br J Cancer (2005) 92(7):1182-7. doi:10.1038/sj.bjc.6602476

107. Ghiringhelli F, Puig PE, Roux S, Parcellier A, Schmitt E, Solary E, et al. Tumor cells convert immature myeloid dendritic cells into TGF-beta-secreting cells inducing CD4+CD25+ regulatory $\mathrm{T}$ cell proliferation. J Exp Med (2005) 202(7):919-29. doi:10.1084/jem.20050463

108. Banerjee DK, Dhodapkar MV, Matayeva E, Steinman RM, Dhodapkar KM. Expansion of FOXP3high regulatory T cells by human dendritic cells (DCs) in vitro and after injection of cytokine-matured DCs in myeloma patients. Blood (2006) 108(8):2655-61. doi:10.1182/blood-2006-03-011353

109. Luo X, Tarbell KV, Yang H, Pothoven K, Bailey SL, Ding R, et al. Dendritic cells with TGF-betal differentiate naive CD4+CD25- T cells into islet-protective Foxp3+ regulatory T cells. Proc Natl Acad Sci U S A (2007) 104(8):2821-6. doi:10.1073/pnas.0611646104

110. Liu VC, Wong LY, Jang T, Shah AH, Park I, Yang X, et al. Tumor evasion of the immune system by converting CD4+CD25- T cells into CD4+CD25+ T regulatory cells: role of tumor-derived TGF-beta. J Immunol (2007) 178(5):2883-92. doi:10.4049/jimmunol.178.5.2883

111. Mancino A, Schioppa T, Larghi P, Pasqualini F, Nebuloni M, Chen IH, et al. Divergent effects of hypoxia on dendritic cell functions. Blood (2008) 112(9):3723-34. doi:10.1182/blood-2008-02-142091

112. Elia AR, Cappello P, Puppo M, Fraone T, Vanni C, Eva A, et al. Human dendritic cells differentiated in hypoxia down-modulate antigen uptake and change their chemokine expression profile. J Leukoc Biol (2008) 84(6):1472-82. doi:10.1189/jlb.0208082

113. Yang M, Ma C, Liu S, Shao Q, Gao W, Song B, et al. HIF-dependent induction of adenosine receptor A2b skews human dendritic cells to a Th2stimulating phenotype under hypoxia. Immunol Cell Biol (2010) 88(2):165-71. doi:10.1038/icb.2009.77

114. Novitskiy SV, Ryzhov S, Zaynagetdinov R, Goldstein AE, Huang Y, Tikhomirov $\mathrm{OY}$, et al. Adenosine receptors in regulation of dendritic cell differentiation and function. Blood (2008) 112(5):1822-31. doi:10.1182/blood-2008-02136325

115. Riboldi E, Musso T, Moroni E, Urbinati C, Bernasconi S, Rusnati M, et al. Cutting edge: proangiogenic properties of alternatively activated dendritic cells. J Immunol (2005) 175(5):2788-92. doi:10.4049/jimmunol.175.5.2788

116. West XZ, Malinin NL, Merkulova AA, Tischenko M, Kerr BA, Borden EC, et al. Oxidative stress induces angiogenesis by activating TLR2 with novel endogenous ligands. Nature (2010) 467(7318):972-6. doi:10.1038/nature09421
117. Montesinos MC, Shaw JP, Yee H, Shamamian P, Cronstein BN. Adenosine $\mathrm{A}(2 \mathrm{~A})$ receptor activation promotes wound neovascularization by stimulating angiogenesis and vasculogenesis. Am J Pathol (2004) 164(6):1887-92. doi:10.1016/S0002-9440(10)63749-2

118. Alfranca A, Lopez-Oliva JM, Genis L, Lopez-Maderuelo D, Mirones I, Salvado $\mathrm{D}$, et al. PGE2 induces angiogenesis via MT1-MMP-mediated activation of the TGFbeta/Alk5 signaling pathway. Blood (2008) 112(4):1120-8. doi:10.1182/blood-2007-09-112268

119. Lebrin F, Deckers M, Bertolino P, Ten Dijke P. TGF-beta receptor function in the endothelium. Cardiovasc Res (2005) 65(3):599-608. doi:10.1016/j.cardiores. 2004.10.036

120. Gabrilovich DI, Chen HL, Girgis KR, Cunningham HT, Meny GM, Nadaf $\mathrm{S}$, et al. Production of vascular endothelial growth factor by human tumors inhibits the functional maturation of dendritic cells. Nat Med (1996) 2(10):1096-103. doi:10.1038/nm1096- 1096

121. Takahashi A, Kono K, Ichihara F, Sugai H, Fujii H, Matsumoto Y. Vascular endothelial growth factor inhibits maturation of dendritic cells induced by lipopolysaccharide, but not by proinflammatory cytokines. Cancer Immunol Immunother (2004) 53(6):543-50. doi:10.1007/s00262-003-0466-8

122. Della Porta M, Danova M, Rigolin GM, Brugnatelli S, Rovati B, Tronconi C, et al. Dendritic cells and vascular endothelial growth factor in colorectal cancer: correlations with clinicobiological findings. Oncology (2005) 68(2-3):276-84. doi:10.1159/000086784

123. Braumuller H, Wieder T, Brenner E, Assmann S, Hahn M, Alkhaled M, et al. T-helper-1-cell cytokines drive cancer into senescence. Nature (2013) 494(7437):361-5. doi:10.1038/nature11824

124. Chu WM. Tumor necrosis factor. Cancer Lett (2013) 328(2):222-5. doi:10. 1016/j.canlet.2012.10.014

125. Weiss JM, Renkl AC, Maier CS, Kimmig M, Liaw L, Ahrens T, et al. Osteopontin is involved in the initiation of cutaneous contact hypersensitivity by inducing Langerhans and dendritic cell migration to lymph nodes. J Exp Med (2001) 194(9):1219-29. doi:10.1084/jem.194.9.1219

126. Renkl AC, Wussler J, Ahrens T, Thoma K, Kon S, Uede T, et al. Osteopontin functionally activates dendritic cells and induces their differentiation toward a Th1-polarizing phenotype. Blood (2005) 106(3):946-55. doi:10.1182/blood2004-08-3228

127. Shinohara ML, Lu L, Bu J, Werneck MB, Kobayashi KS, Glimcher LH, et al. Osteopontin expression is essential for interferon-alpha production by plasmacytoid dendritic cells. Nat Immunol (2006) 7(5):498-506. doi:10.1038/ni1327

128. Caux C, Massacrier C, Vanbervliet B, Dubois B, Van Kooten C, Durand I, et al. Activation of human dendritic cells through CD40 cross-linking. J Exp Med (1994) 180(4):1263-72. doi:10.1084/jem.180.4.1263

129. Verhasselt V, Buelens C, Willems F, De Groote D, Haeffner-Cavaillon N, Goldman M. Bacterial lipopolysaccharide stimulates the production of cytokines and the expression of costimulatory molecules by human peripheral blood dendritic cells: evidence for a soluble CD14-dependent pathway. J Immunol (1997) 158(6):2919-25.

130. Konno S, Hizawa N, Nishimura M, Huang SK. Osteopontin: a potential biomarker for successful bee venom immunotherapy and a potential molecule for inhibiting IgE-mediated allergic responses. Allergol Int (2006) 55(4):355-9. doi:10.2332/allergolint.55.355

131. Means TK, Hayashi F, Smith KD, Aderem A, Luster AD. The toll-like receptor 5 stimulus bacterial flagellin induces maturation and chemokine production in human dendritic cells. J Immunol (2003) 170(10):5165-75. doi:10.4049/ jimmunol.170.10.5165

132. Scimone ML, Lutzky VP, Zittermann SI, Maffia P, Jancic C, Buzzola F, et al. Migration of polymorphonuclear leucocytes is influenced by dendritic cells. Immunology (2005) 114(3):375-85. doi:10.1111/j.1365-2567.2005.02104.x

133. Vermi W, Facchetti F, Riboldi E, Heine H, Scutera S, Stornello S, et al. Role of dendritic cell-derived CXCL13 in the pathogenesis of Bartonella henselae B-rich granuloma. Blood (2006) 107(2):454-62. doi:10.1182/blood-2005-04-1342

134. Piqueras B, Connolly J, Freitas H, Palucka AK, Banchereau J. Upon viral exposure, myeloid and plasmacytoid dendritic cells produce 3 waves of distinct chemokines to recruit immune effectors. Blood (2006) 107(7):2613-8. doi:10.1182/blood-2005-07-2965

135. Albini A, Tosetti F, Benelli R, Noonan DM. Tumor inflammatory angiogenesis and its chemoprevention. Cancer Res (2005) 65(23):10637-41. doi:10.1158/ 0008-5472.CAN-05-3473 
136. Indraccolo S, Gola E, Rosato A, Minuzzo S, Habeler W, Tisato V, et al. Differential effects of angiostatin, endostatin and interferon-alpha(1) gene transfer on in vivo growth of human breast cancer cells. Gene Ther (2002) 9(13):867-78. doi:10.1038/sj.gt.3301703

137. Doyen V, Rubio M, Braun D, Nakajima T, Abe J, Saito H, et al. Thrombospondin 1 is an autocrine negative regulator of human dendritic cell activation. J Exp Med (2003) 198(8):1277-83. doi:10.1084/jem.20030705

138. Rusnati M, Presta M. Extracellular angiogenic growth factor interactions: an angiogenesis interactome survey. Endothelium (2006) 13(2):93-111. doi:10. 1080/10623320600698011

139. Doni A, Michela M, Bottazzi B, Peri G, Valentino S, Polentarutti N, et al. Regulation of PTX3, a key component of humoral innate immunity in human dendritic cells: stimulation by IL-10 and inhibition by IFN-gamma. J Leukoc Biol (2006) 79(4):797-802. doi:10.1189/jlb.0905493

140. Doni A, Peri G, Chieppa M, Allavena P, Pasqualini F, Vago L, et al. Production of the soluble pattern recognition receptor PTX3 by myeloid, but not plasmacytoid, dendritic cells. Eur J Immunol (2003) 33(10):2886-93. doi:10.1002/eji.200324390

141. Gabrilovich DI, Nagaraj S. Myeloid-derived suppressor cells as regulators of the immune system. Nat Rev Immunol (2009) 9(3):162-74. doi:10.1038/nri2506

142. Gabrilovich DI, Ostrand-Rosenberg S, Bronte V. Coordinated regulation of myeloid cells by tumours. Nat Rev Immunol (2012) 12(4):253-68. doi:10.1038/ nri3175

143. Peranzoni E, Zilio S, Marigo I, Dolcetti L, Zanovello P, Mandruzzato S, et al. Myeloid-derived suppressor cell heterogeneity and subset definition. Curr Opin Immunol (2010) 22(2):238-44. doi:10.1016/j.coi.2010.01.021

144. Bunt SK, Sinha P, Clements VK, Leips J, Ostrand-Rosenberg S. Inflammation induces myeloid-derived suppressor cells that facilitate tumor progression. J Immunol (2006) 176(1):284-90. doi:10.4049/jimmunol.176.1.284

145. Shi J, Ikeda K, Maeda Y, Shinagawa K, Ohtsuka A, Yamamura H, et al. Identification of $\mathrm{CD} 123+$ myeloid dendritic cells as an early-stage immature subset with strong tumoristatic potential. Cancer Lett (2008) 270(1):19-29. doi:10.1016/j.canlet.2008.04.048

146. Solito S, Falisi E, Diaz-Montero CM, Doni A, Pinton L, Rosato A, et al. A human promyelocytic-like population is responsible for the immune suppression mediated by myeloid-derived suppressor cells. Blood (2011) 118(8):2254-65. doi:10.1182/blood-2010-12-325753

147. Diaz-Montero CM, Salem ML, Nishimura MI, Garrett-Mayer E, Cole DJ, Montero AJ. Increased circulating myeloid-derived suppressor cells correlate with clinical cancer stage, metastatic tumor burden, and doxorubicincyclophosphamide chemotherapy. Cancer Immunol Immunother (2009) 58(1):49-59. doi:10.1007/s00262-008-0523-4

148. Yang L, DeBusk LM, Fukuda K, Fingleton B, Green-Jarvis B, Shyr Y, et al. Expansion of myeloid immune suppressor $\mathrm{Gr}+\mathrm{CD} 11 \mathrm{~b}+$ cells in tumor-bearing host directly promotes tumor angiogenesis. Cancer Cell (2004) 6(4):409-21. doi:10.1016/j.ccr.2004.08.031

149. Mazzoni A, Bronte V, Visintin A, Spitzer JH, Apolloni E, Serafini P, et al. Myeloid suppressor lines inhibit $\mathrm{T}$ cell responses by an NO-dependent mechanism. J Immunol (2002) 168(2):689-95. doi:10.4049/jimmunol.168.2.689

150. Rodriguez PC, Quiceno DG, Zabaleta J, Ortiz B, Zea AH, Piazuelo MB, et al. Arginase I production in the tumor microenvironment by mature myeloid cells inhibits T-cell receptor expression and antigen-specific T-cell responses. Cancer Res (2004) 64(16):5839-49. doi:10.1158/0008-5472.CAN-04-0465

151. Srivastava MK, Sinha P, Clements VK, Rodriguez P, Ostrand-Rosenberg S. Myeloid-derived suppressor cells inhibit T-cell activation by depleting cystine and cysteine. Cancer Res (2010) 70(1):68-77. doi:10.1158/0008-5472.CAN09-2587

152. Corzo CA, Condamine T, Lu L, Cotter MJ, Youn JI, Cheng P, et al. HIFlalpha regulates function and differentiation of myeloid-derived suppressor cells in the tumor microenvironment. J Exp Med (2010) 207(11):2439-53. doi:10.1084/jem.20100587

153. Hanson EM, Clements VK, Sinha P, Ilkovitch D, Ostrand-Rosenberg S. Myeloid-derived suppressor cells down-regulate L-selectin expression on CD4+ and CD8+ T cells. J Immunol (2009) 183(2):937-44. doi:10.4049/ jimmunol.0804253

154. Molon B, Ugel S, Del Pozzo F, Soldani C, Zilio S, Avella D, et al. Chemokine nitration prevents intratumoral infiltration of antigen-specific T cells. J Exp Med (2011) 208(10):1949-62. doi:10.1084/jem.20101956
155. Hoechst B, Voigtlaender T, Ormandy L, Gamrekelashvili J, Zhao F, Wedemeyer $\mathrm{H}$, et al. Myeloid derived suppressor cells inhibit natural killer cells in patients with hepatocellular carcinoma via the NKp30 receptor. Hepatology (2009) 50(3):799-807. doi:10.1002/hep.23054

156. Elkabets M, Ribeiro VS, Dinarello CA, Ostrand-Rosenberg S, Di Santo JP, Apte RN, et al. IL-1beta regulates a novel myeloid-derived suppressor cell subset that impairs NK cell development and function. Eur J Immunol (2010) 40(12):3347-57. doi:10.1002/eji.201041037

157. Zhang J, Alston MA, Huang H, Rabin RL. Human T cell cytokine responses are dependent on multidrug resistance protein-1. Int Immunol (2006) 18(3):485-93. doi:10.1093/intimm/dxh389

158. Serafini P, Mgebroff S, Noonan K, Borrello I. Myeloid-derived suppressor cells promote cross-tolerance in B-cell lymphoma by expanding regulatory $\mathrm{T}$ cells. Cancer Res (2008) 68(13):5439-49. doi:10.1158/0008-5472.CAN-07-6621

159. Pan PY, Ma G, Weber KJ, Ozao-Choy J, Wang G, Yin B, et al. Immune stimulatory receptor CD40 is required for T-cell suppression and $\mathrm{T}$ regulatory cell activation mediated by myeloid-derived suppressor cells in cancer. Cancer Res (2010) 70(1):99-108. doi:10.1158/0008-5472.CAN-09- 1882

160. Hoechst B, Gamrekelashvili J, Manns MP, Greten TF, Korangy F. Plasticity of human Th17 cells and iTregs is orchestrated by different subsets of myeloid cells. Blood (2011) 117(24):6532-41. doi:10.1182/blood-2010-11-317321

161. Sawant A, Deshane J, Jules J, Lee CM, Harris BA, Feng X, et al. Myeloid-derived suppressor cells function as novel osteoclast progenitors enhancing bone loss in breast cancer. Cancer Res (2013) 73(2):672-82. doi:10.1158/0008-5472.CAN12-2202

162. Zhang H, Maric I, DiPrima MJ, Khan J, Orentas RJ, Kaplan RN, et al. Fibrocytes represent a novel MDSC subset circulating in patients with metastatic cancer. Blood (2013) 122(7):1105-13. doi:10.1182/blood-2012-08-449413

163. Cooper MA, Fehniger TA, Caligiuri MA. The biology of human natural killer-cell subsets. Trends Immunol (2001) 22(11):633-40. doi:10.1016/S14714906(01)02060-9

164. Santoni A, Zingoni A, Cerboni C, Gismondi A. Natural killer (NK) cells from killers to regulators: distinct features between peripheral blood and decidual NK cells. Am J Reprod Immunol (2007) 58(3):280-8. doi:10.1111/j.1600-0897. 2007.00513.x

165. Vacca P, Moretta L, Moretta A, Mingari MC. Origin, phenotype and function of human natural killer cells in pregnancy. Trends Immunol (2011) 32(11):517-23. doi:10.1016/j.it.2011.06.013

166. Carrega P, Morandi B, Costa R, Frumento G, Forte G, Altavilla G, et al. Natural killer cells infiltrating human nonsmall-cell lung cancer are enriched in CD56 bright CD16(-) cells and display an impaired capability to kill tumor cells. Cancer (2008) 112(4):863-75. doi:10.1002/cncr.23239

167. Platonova S, Cherfils-Vicini J, Damotte D, Crozet L, Vieillard V, Validire $\mathrm{P}$, et al. Profound coordinated alterations of intratumoral NK cell phenotype and function in lung carcinoma. Cancer Res (2011) 71(16):5412-22. doi:10.1158/0008-5472.CAN-10-4179

168. Allan DS, Rybalov B, Awong G, Zuniga-Pflucker JC, Kopcow HD, Carlyle JR, et al. TGF-beta affects development and differentiation of human natural killer cell subsets. Eur J Immunol (2010) 40(8):2289-95. doi:10.1002/ eji.200939910

169. Keskin DB, Allan DS, Rybalov B, Andzelm MM, Stern JN, Kopcow HD, et al. TGFbeta promotes conversion of CD16+ peripheral blood NK cells into CD16NK cells with similarities to decidual NK cells. Proc Natl Acad Sci U S A (2007) 104(9):3378-83. doi:10.1073/pnas.0611098104

170. Nanni P, Nicoletti G, Landuzzi L, Croci S, Murgo A, Palladini A, et al. High metastatic efficiency of human sarcoma cells in Rag2/gammac double knockout mice provides a powerful test system for antimetastatic targeted therapy. Eur J Cancer (2010) 46(3):659-68. doi:10.1016/j.ejca.2009.11.018

171. Coupland LA, Chong BH, Parish CR. Beware of NK cells in pre-clinical metastasis models. Clin Exp Metastasis (2013) 30(7):945-7. doi:10.1007/s10585-0139582-9

172. Albini A, Noonan DM. The 'chemoinvasion' assay, 25 years and still going strong: the use of reconstituted basement membranes to study cell invasion and angiogenesis. Curr Opin Cell Biol (2010) 22(5):677-89. doi:10.1016/j.ceb. 2010.08.017

173. Noonan DM, Pennesi G, Albini A. Invasion and metastasis. In: Bagley RG, editor. The Tumor Microenvironment: Cancer Drug Discovery and Development. New York, NY: Springer Science+Business Media (2010). p. 213-28. 
174. Wels J, Kaplan RN, Rafii S, Lyden D. Migratory neighbors and distant invaders: tumor-associated niche cells. Genes Dev (2008) 22(5):559-74. doi:10.1101/gad. 1636908

175. Paolino M, Choidas A, Wallner S, Pranjic B, Uribesalgo I, Loeser S, et al. The E3 ligase Cbl-b and TAM receptors regulate cancer metastasis via natural killer cells. Nature (2014) 507(7493):508-12. doi:10.1038/nature12998

176. Motz GT, Coukos G. The parallel lives of angiogenesis and immunosuppression: cancer and other tales. Nat Rev Immunol (2011) 11(10):702-11. doi:10.1038/nri3064

177. Wu Y, Borde M, Heissmeyer V, Feuerer M, Lapan AD, Stroud JC, et al. FOXP3 controls regulatory $\mathrm{T}$ cell function through cooperation with NFAT. Cell (2006) 126(2):375-87. doi:10.1016/j.cell.2006.05.042

178. Yang L, Pang Y, Moses HL. TGF-beta and immune cells: an important regulatory axis in the tumor microenvironment and progression. Trends Immunol (2010) 31(6):220-7. doi:10.1016/j.it.2010.04.002

179. Facciabene A, Peng X, Hagemann IS, Balint K, Barchetti A, Wang LP, et al. Tumour hypoxia promotes tolerance and angiogenesis via CCL28 and T(reg) cells. Nature (2011) 475(7355):226-30. doi:10.1038/nature10169

180. Bourbie-Vaudaine S, Blanchard N, Hivroz C, Romeo PH. Dendritic cells can turn CD4+ T lymphocytes into vascular endothelial growth factor-carrying cells by intercellular neuropilin-1 transfer. J Immunol (2006) 177(3):1460-9. doi:10.4049/jimmunol.177.3.1460

181. Sarris M, Andersen KG, Randow F, Mayr L, Betz AG. Neuropilin-1 expression on regulatory $\mathrm{T}$ cells enhances their interactions with dendritic cells during antigen recognition. Immunity (2008) 28(3):402-13. doi:10.1016/j.immuni. 2008.01.012

182. Tiemessen CT, Kuhn L. CC chemokines and protective immunity: insights gained from mother-to-child transmission of HIV. Nat Immunol (2007) 8(3):219-22. doi:10.1038/ni0307-219

183. Bais AG, Beckmann I, Lindemans J, Ewing PC, Meijer CJ, Snijders PJ, et al. A shift to a peripheral Th2-type cytokine pattern during the carcinogenesis of cervical cancer becomes manifest in CIN III lesions. J Clin Pathol (2005) 58(10):1096-100. doi:10.1136/jcp.2004.025072

184. Zheng Z, Tan C, Xiang G, Mai G, Liu X. Deleted in liver cancer-1 inhibits cell growth and tumorigenicity in human pancreatic cancer. Oncol Lett (2013) 6(2):521-4. doi:10.3892/ol.2013.1415

185. Freedman RS, Kudelka AP, Kavanagh JJ, Verschraegen C, Edwards CL, Nash M, et al. Clinical and biological effects of intraperitoneal injections of recombinant interferon-gamma and recombinant interleukin 2 with or without tumorinfiltrating lymphocytes in patients with ovarian or peritoneal carcinoma. Clin Cancer Res (2000) 6(6):2268-78.

186. Di Carlo E, Comes A, Orengo AM, Rosso O, Meazza R, Musiani P, et al. IL21 induces tumor rejection by specific CTL and IFN-gamma-dependent CXC chemokines in syngeneic mice. J Immunol (2004) 172(3):1540-7. doi:10.4049/ jimmunol.172.3.1540

187. Balza E, Mortara L, Sassi F, Monteghirfo S, Carnemolla B, Castellani P, et al. Targeted delivery of tumor necrosis factor-alpha to tumor vessels induces a therapeutic $\mathrm{T}$ cell-mediated immune response that protects the host against syngeneic tumors of different histologic origin. Clin Cancer Res (2006) 12(8):2575-82. doi:10.1158/1078-0432.CCR-05-2448

188. Mortara L, Castellani P, Meazza R, Tosi G, De Lerma Barbaro A, Procopio FA, et al. CIITA-induced MHC class II expression in mammary adenocarcinoma leads to a Th1 polarization of the tumor microenvironment, tumor rejection, and specific antitumor memory. Clin Cancer Res (2006) 12(11 Pt 1):3435-43. doi:10.1158/1078-0432.CCR-06-0165

189. De Santo C, Serafini P, Marigo I, Dolcetti L, Bolla M, Del Soldato P, et al. Nitroaspirin corrects immune dysfunction in tumor-bearing hosts and promotes tumor eradication by cancer vaccination. Proc Natl Acad Sci US A (2005) 102(11):4185-90. doi:10.1073/pnas.0409783102

190. Calcinotto A, Grioni M, Jachetti E, Curnis F, Mondino A, Parmiani G, et al. Targeting TNF-alpha to neoangiogenic vessels enhances lymphocyte infiltration in tumors and increases the therapeutic potential of immunotherapy. J Immunol (2012) 188(6):2687-94. doi:10.4049/jimmunol.1101877

191. Gallina G, Dolcetti L, Serafini P, De Santo C, Marigo I, Colombo MP, et al. Tumors induce a subset of inflammatory monocytes with immunosuppressive activity on CD8+ T cells. J Clin Invest (2006) 116(10):2777-90. doi:10.1172/JCI28828
192. Movahedi K, Guilliams M, Van den Bossche J, Van den Bergh R, Gysemans $\mathrm{C}$, Beschin A, et al. Identification of discrete tumor-induced myeloid-derived suppressor cell subpopulations with distinct T cell-suppressive activity. Blood (2008) 111(8):4233-44. doi:10.1182/blood-2007-07-099226

193. Fridman WH, Pages F, Sautes-Fridman C, Galon J. The immune contexture in human tumours: impact on clinical outcome. Nat Rev Cancer (2012) 12(4):298-306. doi:10.1038/nrc3245

194. Galon J, Costes A, Sanchez-Cabo F, Kirilovsky A, Mlecnik B, Lagorce-Pages $\mathrm{C}$, et al. Type, density, and location of immune cells within human colorectal tumors predict clinical outcome. Science (2006) 313(5795):1960-4. doi:10.1126/science. 1129139

195. Bindea G, Mlecnik B, Tosolini M, Kirilovsky A, Waldner M, Obenauf AC, et al. Spatiotemporal dynamics of intratumoral immune cells reveal the immune landscape in human cancer. Immunity (2013) 39(4):782-95. doi:10.1016/j. immuni.2013.10.003

196. Remark R, Alifano M, Cremer I, Lupo A, Dieu-Nosjean MC, Riquet M, et al. Characteristics and clinical impacts of the immune environments in colorectal and renal cell carcinoma lung metastases: influence of tumor origin. Clin Cancer Res (2013) 19(15):4079-91. doi:10.1158/1078-0432.CCR-12-3847

197. Di Carlo E, Comes A, Basso S, De Ambrosis A, Meazza R, Musiani P, et al. The combined action of IL-15 and IL-12 gene transfer can induce tumor cell rejection without T and NK cell involvement. J Immunol (2000) 165(6):3111-8. doi:10.4049/jimmunol.165.6.3111

198. Jarnicki AG, Lysaght J, Todryk S, Mills KH. Suppression of antitumor immunity by IL-10 and TGF-beta-producing T cells infiltrating the growing tumor: influence of tumor environment on the induction of CD4+ and CD8+ regulatory T cells. J Immunol (2006) 177(2):896-904. doi:10.4049/jimmunol.177.2.896

199. Kiniwa Y, Miyahara Y, Wang HY, Peng W, Peng G, Wheeler TM, et al. CD8+ Foxp3+ regulatory T cells mediate immunosuppression in prostate cancer. Clin Cancer Res (2007) 13(23):6947-58. doi:10.1158/1078-0432.CCR-07-0842

200. Shafer-Weaver KA, Anderson MJ, Stagliano K, Malyguine A, Greenberg NM, Hurwitz AA. Cutting edge: tumor-specific CD8+ T cells infiltrating prostatic tumors are induced to become suppressor cells. J Immunol (2009) 183(8):4848-52. doi:10.4049/jimmunol.0900848

201. Niederkorn JY. Emerging concepts in CD8(+) T regulatory cells. Curr Opin Immunol (2008) 20(3):327-31. doi:10.1016/j.coi.2008.02.003

202. Coronella JA, Telleman P, Kingsbury GA, Truong TD, Hays S, Junghans RP. Evidence for an antigen-driven humoral immune response in medullary ductal breast cancer. Cancer Res (2001) 61(21):7889-99.

203. Germain C, Gnjatic S, Tamzalit F, Knockaert S, Remark R, Goc J, et al. Presence of $\mathrm{B}$ cells in tertiary lymphoid structures is associated with a protective immunity in lung cancer patients. Am J Respir Crit Care Med (2014) 189(7):832-44. doi:10.1164/rccm.201309-1611OC

204. Qin Z, Richter G, Schuler T, Ibe S, Cao X, Blankenstein T. B cells inhibit induction of T cell-dependent tumor immunity. Nat Med (1998) 4(5):627-30. doi:10.1038/nm0598-627

205. de Visser KE, Korets LV, Coussens LM. De novo carcinogenesis promoted by chronic inflammation is B lymphocyte dependent. Cancer Cell (2005) 7(5):411-23. doi:10.1016/j.ccr.2005.04.014

206. Schioppa T, Moore R, Thompson RG, Rosser EC, Kulbe H, Nedospasov S, et al. B regulatory cells and the tumor-promoting actions of TNF-alpha during squamous carcinogenesis. Proc Natl Acad Sci U S A (2011) 108(26):10662-7. doi:10.1073/pnas.1100994108

207. Andreu P, Johansson M, Affara NI, Pucci F, Tan T, Junankar S, et al. FcRgamma activation regulates inflammation-associated squamous carcinogenesis. Cancer Cell (2010) 17(2):121-34. doi:10.1016/j.ccr.2009.12.019

208. DeNardo DG, Andreu P, Coussens LM. Interactions between lymphocytes and myeloid cells regulate pro- versus anti-tumor immunity. Cancer Metastasis Rev (2010) 29(2):309-16. doi:10.1007/s10555-010-9223-6

209. Gunderson AJ, Coussens LM. B cells and their mediators as targets for therapy in solid tumors. Exp Cell Res (2013) 319(11):1644-9. doi:10.1016/j.yexcr.2013. 03.005

210. Ammirante M, Luo JL, Grivennikov S, Nedospasov S, Karin M. B-cell-derived lymphotoxin promotes castration-resistant prostate cancer. Nature (2010) 464(7286):302-5. doi:10.1038/nature08782

211. Mauri C, Bosma A. Immune regulatory function of B cells. Annu Rev Immunol (2012) 30:221-41. doi:10.1146/annurev-immunol-020711-074934 
212. Maruotti N, Crivellato E, Cantatore FP, Vacca A, Ribatti D. Mast cells in rheumatoid arthritis. Clin Rheumatol (2007) 26(1):1-4. doi:10.1007/s10067006-0305-3

213. Ribatti D, Crivellato E, Molica S. Mast cells and angiogenesis in haematological malignancies. Leuk Res (2009) 33(7):876-9. doi:10.1016/j.leukres.2009.02.028

214. Ribatti D, Crivellato E, Roccaro AM, Ria R, Vacca A. Mast cell contribution to angiogenesis related to tumour progression. Clin Exp Allergy (2004) 34(11):1660-4. doi:10.1111/j.1365-2222.2004.02104.x

215. Crivellato E, Nico B, Ribatti D. Mast cells and tumour angiogenesis: new insight from experimental carcinogenesis. Cancer Lett (2008) 269(1):1-6. doi:10.1016/j.canlet.2008.03.031

216. Nico B, Mangieri D, Crivellato E, Vacca A, Ribatti D. Mast cells contribute to vasculogenic mimicry in multiple myeloma. Stem Cells Dev (2008) 17(1):19-22. doi:10.1089/scd.2007.0132

217. Coussens LM, Raymond WW, Bergers G, Laig-Webster M, Behrendtsen O, Werb $\mathrm{Z}$, et al. Inflammatory mast cells up-regulate angiogenesis during squamous epithelial carcinogenesis. Genes Dev (1999) 13(11):1382-97. doi:10.1101/gad. 13.11.1382

218. Ranieri G, Ammendola M, Patruno R, Celano G, Zito FA, Montemurro S, et al. Tryptase-positive mast cells correlate with angiogenesis in early breast cancer patients. Int J Oncol (2009) 35(1):115-20. doi:10.3892/ijo_00000319

219. Soucek L, Lawlor ER, Soto D, Shchors K, Swigart LB, Evan GI. Mast cells are required for angiogenesis and macroscopic expansion of Myc-induced pancreatic islet tumors. Nat Med (2007) 13(10):1211-8. doi:10.1038/nm1649

220. Galinsky DS, Nechushtan H. Mast cells and cancer - no longer just basic science. Crit Rev Oncol Hematol (2008) 68(2):115-30. doi:10.1016/j.critrevonc. 2008.06.001

221. Liu J, Divoux A, Sun J, Zhang J, Clement K, Glickman JN, et al. Genetic deficiency and pharmacological stabilization of mast cells reduce diet-induced obesity and diabetes in mice. Nat Med (2009) 15(8):940-5. doi:10.1038/nm.1994

222. Comito G, Giannoni E, Segura CP, Barcellos-de-Souza P, Raspollini MR, Baroni $\mathrm{G}$, et al. Cancer-associated fibroblasts and M2-polarized macrophages synergize during prostate carcinoma progression. Oncogene (2014) 33(19):2423-31. doi:10.1038/onc.2013.191

223. Feoktistov I, Ryzhov S, Goldstein AE, Biaggioni I. Mast cell-mediated stimulation of angiogenesis: cooperative interaction between $\mathrm{A} 2 \mathrm{~B}$ and $\mathrm{A} 3$ adenosine receptors. Circ Res (2003) 92(5):485-92. doi:10.1161/01.RES.0000061572. 10929.2D

224. Gabbiani G, Ryan GB, Majne G. Presence of modified fibroblasts in granulation tissue and their possible role in wound contraction. Experientia (1971) 27(5):549-50. doi:10.1007/BF02147594

225. Dvorak HF. Tumors: wounds that do not heal. Similarities between tumor stroma generation and wound healing. N Engl J Med (1986) 315(26):1650-9. doi:10.1056/NEJM198612253152606

226. Cirri P, Chiarugi P. Cancer associated fibroblasts: the dark side of the coin. Am J Cancer Res (2011) 1(4):482-97. doi:10.1007/s10555-011-9340-x

227. Matsuo Y, Ochi N, Sawai H, Yasuda A, Takahashi H, Funahashi H, et al. CXCL8/IL-8 and CXCL12/SDF-1alpha co-operatively promote invasiveness and angiogenesis in pancreatic cancer. Int J Cancer (2009) 124(4):853-61. doi:10.1002/ijc. 24040

228. Orimo A, Gupta PB, Sgroi DC, Arenzana-Seisdedos F, Delaunay T, Naeem R, et al. Stromal fibroblasts present in invasive human breast carcinomas promote tumor growth and angiogenesis through elevated SDF-1/CXCL12 secretion. Cell (2005) 121(3):335-48. doi:10.1016/j.cell.2005.02.034

Conflict of Interest Statement: The authors declare that the research was conducted in the absence of any commercial or financial relationships that could be construed as a potential conflict of interest.

Received: 29 March 2014; paper pending published: 21 April 2014; accepted: 16 May 2014; published online: 02 July 2014.

Citation: Bruno A, Pagani A, Pulze L, Albini A, Dallaglio K, Noonan DM and Mortara L (2014) Orchestration of angiogenesis by immune cells. Front. Oncol. 4:131. doi: 10.3389/fonc.2014.00131

This article was submitted to Tumor Immunity, a section of the journal Frontiers in Oncology.

Copyright (c) 2014 Bruno, Pagani, Pulze, Albini, Dallaglio, Noonan and Mortara. This is an open-access article distributed under the terms of the Creative Commons Attribution License (CC BY). The use, distribution or reproduction in other forums is permitted, provided the original author(s) or licensor are credited and that the original publication in this journal is cited, in accordance with accepted academic practice. No use, distribution or reproduction is permitted which does not comply with these terms. 